\title{
Espacios, discursos y modos de habitar Chimbote en Hombres de mar, (de óscar Colchado Lucio). Hacia una tradición de la poética de la frontera chimbotana.
}

\section{Resumen}

El presente trabajo estudia la novela Hombres de mar desde la conjugación de los fenómenos urbanos y literarios latinoamericanos recientes. El escenario es la ciudad-puerto de Chimbote, y el discurso, un relato que asume el conflicto de poderes entre los intereses del capital, que hizo del puerto el más grande de explotación pesquera del mundo, y las instancias comunitarias de resistencia, representadas, metonímicamente, por la bolichera Flor de Chimbote y el Colegio Politécnico, que agrupan a pescadores y estudiantes, respectivamente. El espacio se configura así en el diálogo de los universos públicos y privados que envuelve las distintas actividades del puerto: la pesca, el estudio, la fiesta y la política. Todas estas voces se verán expuestas en el espacio público por excelencia: el ágora, zona en la que se debaten las fuerzas del poder. La novela, un relato interdiscursivo, problematiza la realidad como un reclamo sociopolítico, pero también como una propuesta alternativa de rehabitar el histórico puerto peruano. De esta forma, restituye su memoria y, a través de ella, reafirma y reactualiza el continuum de una rica tradición literaria chimbotana.

Palabras claves

Chimbote, literatura peruana contemporánea, espacio urbano-porteño, interdiscursividad histórica, mítica y ficcional.

\footnotetext{
Resumo

O presente trabalho estuda o romance Hombres de mar a partir da conjugação dos fenômenos urbanos e literários latino-americanos recentes. 0 cenário é a cidade portuária de Chimbote, e o discurso, um relato que assume o conflito de poderes entre os interesses do capital, que fez do porto o maior da indústria mundial da pesca, e as instâncias comunitárias de resistência, representadas, metonimicamente, pelo barco de pesca Flor de Chimbote e pelo Colégio Politécnico, que reúnem pescadores e estudantes, respectivamente. Assim, o espaço se configura no diálogo dos universos públicos e privados, que envolve as diferentes
} 
atividades do porto: a pesca, o estudo, a festa e a política. Todas essas vozes ver-se-ão expostas no espaço público por excelência: a ágora, zona em que se debatem as forças do poder. 0 romance, um relato interdiscursivo, problematiza a realidade como uma reivindicação sociopolítica, mas também como uma proposta alternativa para reabitar o histórico porto peruano. Dessa forma, restitui a memória do porto e, através de ela, reafirma e reatualiza o continuum de uma rica tradição literária chimbotana.

Palavras-chaves

Chimbote, literatura peruana contemporânea, espaço urbano-portenho, interdiscursividade histórica, mítica e ficcional.

\begin{abstract}
This work studies the novel Hombres de mar from the conjugation of the Latin American recent urban and literary phenomena. The stage is the city-port of Chimbote. The discourse is a narration that assumes the conflict of powers between the interests of capital (that transformed the port into the biggest place of fishing exploitation of the world) and the communitarian instances of resistance (represented metonymically by the bolichera named Flor de Chimbote and the Polytechnic School that bring together fishermen and students, respectively). The space configures itself in the dialogue of the public and private universes that involves the different activities of the port: the fishing, the study, the party and the politics. All these voices will be exposed in the public space by excellence: the agora, zone where the debate of the powers takes place. The novel, an interdiscursive narrative, problematizes the reality as a social and political demand but also as an alternative proposal to re-inhabit the historic Peruvian port. In this way the novel restitutes the memory of the port and, through it, reaffirms and re-actualizes the continuum of the rich literary tradition from Chimbote.
\end{abstract}

Keywords Chimbote; contemporary peruvian literature; urban-porteño space; historic, mythical and fictional interdiscursivity.

Hombres de mar es la historia de los últimos treinta años del siglo $\mathrm{XX}$ del puerto de Chimbote. Un período decisivo de tres décadas que afecta los planos social, económico, político y cultural del puerto y en su conjunto del Perú en el umbral del nuevo milenio. Sirven como referentes inaugurales en la trama de la novela: el golpe militar perpetrado por Velasco y que destituye a Belaúnde, en 1968; el fin de la bonanza de la pesca; el terremoto que sacude fuertemente las costas del departamento de Ancash, en 1970, y, apenas unos meses antes del sismo, el suicidio de José María Arguedas, en la Universidad Agraria La Molina, en Lima, en diciembre del mismo año. Ahora, como hitos que cierran el período en que se circunscribe la obra, se cuentan, en el 2000: la renuncia — por fax y 
CATEDRAL TOMADA: Revista de crítica literaria latinoamericana / Journal of Latin American Literary Criticism Espacios, discursos y modos de habitar Chimbote en Hombres de mar (de Óscar Colchado Lucio). Hacia una tradición de la poética de la frontera chimbotana.

desde Tokio - de Fujimori a la presidencia, poniendo fin a un largo mandato marcado por abusos, escándalos y corrupción; la Marcha de los Cuatro Suyos que va a ubicar más tarde a Alejandro Toledo en el gobierno; el comienzo del fin del terrorismo que derivará luego en el narcoterrorismo y que, en el caso específico de Chimbote, reemplazará la extracción de la anchoveta por el no menos lucrativo negocio de la coca. Tres décadas (1970-2000), así, que abren y cierran un ciclo en la historia del puerto y que Colchado va a recorrer a través de sus más de quinientas páginas en la que me atrevo a llamar la última gran novela sociopolítica peruana.

La obra se inicia y se va a desarrollar a partir del relato reproducido de un manuscrito hallado entre las pertenencias de Manuel Rojas Padilla, senderista muerto a balazos por paramilitares, en Lima, el 29 de agosto de 19891. En no más de tres planas rememora una historia de amor, de lucha social, de deseos colectivos de un grupo de jóvenes estudiantes del Politécnico de Chimbote, protagonistas de la que fue la gran huelga de los pescadores del puerto. En estas páginas suyas, escritas en cuaderno y que espera algún día sean llevadas a una novela, el guerrillero pasa revista a sus compañeros, sus vidas, sus pasiones, sus amores. Todo eso propio de la primera juventud, de muchachos de barrio criados en la atmósfera chimbotana de los setenta. Quizá adivinando el destino que le deparaba como revolucionario, Rojas Padilla aporta con la materia prima, breves apuntes biográficos, unos cuantos datos históricos precisos -propios del manuscrito encontrado-, de los que se vale Colchado para asumir - $\mathrm{O}$ "transcribir"- el desafío de contar la historia de una generación que en su desenvolviendo va a dar cuenta de los profundos conflictos sociales que marcaron entonces el destino del Perú.

\footnotetext{
1 Al final de la novela se detalla que la muerte de Rojas Padilla acontece en el cerro El Pino, en Lima. Como senderista formó parte de un comando que atacó con bombas a militares que iban en un camión de la escolta presidencial. Después de eso la policía los rodeó y aniquiló. La historia de Rojitas la trabaja en extenso Óscar Colchado en su novela El cerco de Lima (Lima: Editorial Mesa Redonda, 2013).
} 
Las 500 páginas que siguen es la recreación de la vida de estos personajes apenas nombrados en ese manuscrito ajado, con sudor y sangre de guerrillero senderista, pero que va a dar a Óscar Colchado la excusa suficiente para retratar una parte de la historia de la nación peruana. Efectivamente, el autor reescribe un episodio nacional de treinta años, intermediado por un grupo de amigos estudiantes de secundaria que asumirá, como muchos, el momento histórico que le tocó vivir. Adolescencia y revolución son para estos jóvenes una y la misma cosa; y en ese clima crecen y se desarrollan, hasta que la muerte o los distintos caminos que adultos toman, los separan para siempre; aunque marcados sí, como sólo esos años pueden marcar, por ese espíritu de lucha social que el puerto y sus trabajadores les impregnó tempranamente.

Las tres partes en que se divide la novela (cada una de más de ciento cincuenta páginas) funcionan como un conjunto de sucesos que se intercalan dentro de una dinámica espacio-temporal que revela el proceso vital que vive la sociedad peruana de esos años y que en los personajes está marcada por el tránsito de la adolescencia a la adultez; que equivale a decir también del encanto a la decepción, del anhelo revolucionario a la guerra de todos contra todos; en un contexto que refleja fielmente la ciudad moderna en tensión, con el agregado de que no es cualquier ciudad: Chimbote llegó a ser en la década del sesenta el primer puerto pesquero del mundo. Un hecho que transformó a la ciudad como a su población toda, convirtiéndola en fenómeno urbano, industrial y cultural único en la región. Ese que en su asombro hizo a Arguedas escribir su novela-testimonio póstuma.

Como en una suerte de relevo de voces, la historia avanza como narración no siempre o casi nunca de manera cronológica lineal aislada, sino como un complejo tejido que va a progresar como relato en la medida que se cruzan los universos estructurales que la sustentan. En una historia particular que termina siendo colectiva, que acaba diluyéndose en la comunidad, radica el esfuerzo narrativo de la novela. En ese proceso escritural tiene un valor destacado la presencia del imaginario mítico andino, el que pese a ocupar, en comparación al 
conjunto, una mínima parte —a modo de apéndice-, justifica no obstante su plena inclusión acorde a un compromiso integral con la realidad a la cual el narrador se haya comprometido ${ }^{2}$. La incorporación de seres míticos, de tiempos y

2 El suceso mítico-religioso avanza como correlato a la historia central, funciona como hecho aparte hasta la revelación de que El Viejo Tijera y Mariela Salinas, con roles concretos dentro de la historia, mantienen un vínculo directo con el mito indígena de la cultura moche. La historia se remonta al principio de los tiempos, a un estado previo a la fundación de Chimbote. Guácharo, Mellizo Marino acude a la bahía para hallar a la diosa Lluvia y solicitarle que haga llover sobre el desierto. Ella se niega por lo que éste decide secuestrarla, pero la intervención de Mellizo Terrestre, su hermano y acérrimo enemigo, impiden que logre su propósito. Hecho que desata una feroz batalla entre los hermanos y todos sus súbditos: animales y seres marinos contra los hombres y mujeres de la bahía, convertidos en guerreros. Mellizo Terrestre es derribado, le toman prisionero, lo matan y lo arrojan al subsuelo. Tiempo después, un ave curandera le resucita y le informa que la diosa Lluvia, desde el día que sufrió la derrota, se encuentra en manos de su hermano Mellizo Marino. Luego de sortear una serie de vicisitudes, llega al lugar donde está presa y sigiloso percibe cómo su carcelero, muy irritado, le exige que haga llover, a lo que ésta, desconsolada, le explica que no puede, que eso no depende de ella, sino de Ai-Apaec, dios degollador, castigador-creador, máxima divinidad y padre de los mellizos. Razón suficiente para que Mellizo Marino decida sacrificarla, pero en eso aparece el Dios Mayor y la salva, llevándosela a la morada celeste. Estando en deuda Mellizo Marino con su padre Ai-Apaec, por intentar matar a la diosa Lluvia, busca enmendar la falta ofreciéndole lo único capaz de satisfacerle y que además permite la armonía, el equilibrio natural del universo: sangre de los pescadores de la bahía. Para eso se alía con Shinam, la diosa Luna, quien ya tiene un plan: animar los objetos de trabajo de los pescadores para que se tornen contra ellos. Estrategia que resulta. Los utensilios vencen a sus dueños, los que son apresados en una is la para ser luego sacrificados y cuya sangre será ofrecida al iracundo e insaciable Ai-Apaec. Será el mismo Mellizo Marino quien le llevará la ofrenda hacia su morada, el Pachap Sapin, lugar donde se juntan el cielo y el mar. Sin embargo los vientos hacen que hierre la ruta y quede al garete, perdido en la vastedad del mar. Y como la sangre no llega a su destinatario, ya que en ese torbellino es derramada, Ai-Apaec furioso hace que se desate una lluvia torrencial, anunciando un cataclismo. Pero no conforme con eso, convierte a Mellizo Marino, como castigo por su doble sacrilegio, en una horripilante ave condenada a vivir en la oscuridad de los acantilados, de donde podrá salir sólo a veces y convertido en alcatraz o en figura humana. En una de esas salidas, muchos siglos después del castigo y muchos antes del presente, conoce en las inmediaciones de un río a Yéncala, una princesa de quien se enamora perdidamente. Pero ella no le corresponde debido a que ya tenía prometido: Fanllucap, joven pescador chimbotano. Astuto y perverso Mellizo Marino, decide ahora eliminar al pescador para quedarse con Yéncala. Lo mata y para acceder a ella toma la apariencia de éste, no generando duda en la princesa. Felices, yendo a construir su hogar, son interceptados por Shinam, la Luna, su antigua aliada, quien se da cuenta del engaño. Al verse descubierto Mellizo Marino por la diosa, recobra su antigua figura y huye. Desconsolada y sin entender nada, Yéncala queda abandonada y triste, pero para no sufrir una eternidad, una indulgente Shinam decide petrificarla adosándola en una isleta de la isla Blanca. Cuando Mellizo Marino vuelve por Yéncala se da cuenta del estado en que se halla su enamorada, desconsolado llora y maldice a Shinam. Con los siglos, al volver otra vez, descubre que la figura de Yéncala añadida a la roca ya no está, ha desaparecido en forma inadvertida. Pe ro lo cierto es que Yéncala se ha encarnado en la actual Mariela Salinas, la muchacha pobre del barrio San Isidro de la industrializada Chimbote, que ignora por completo su pasado remoto, su otra vida mágica. No así Mellizo Marino que sigue siendo la misma ave horrible y el mismo enamorado de siempre. Sin embargo sus mañas y torcidos propósitos no cesarán hasta conseguir el amor de YéncalaMariela. Y decide que para recibir el perdón de Ai-Apaec, y así dejar esa condición de ave que le condena y no le permite acceder a la princesa, debe brindarle la sangre tibia de esos altivos 
categorías trasmundanas, opera en este sentido como elemento discursivo, recurso estético y factor real-simbólico que en su intertextualidad le da a la obra el espesor y complejidad que como literatura peruana contemporánea exige. Se hace cargo, a través de este empeño totalizador y restitutivo, del conflicto entre tradición y modernidad que, como queda manifiestamente demostrado, no ha dejado nunca de estar presente en la sociedad peruana. Consigue con esto la novela un valor que le da vigencia y legitimidad dentro de las letras peruanas del último tiempo.

En este contexto se aborda Chimbote, en calidad de puerto como de espacio urbano. Hombres de mar es novela urbana como lo fueron en su momento Adán Buenosayres (1948), La región más transparente (1958), Trilogía sucia de La Habana (1998), los cuentos de Ribeyro, Congrains y Reynoso sobre Lima y un larguísimo etcétera. De modo que al retratarse acá el puerto como ciudad, se asumen en ella conflictos propios como el de la interacción entre lo público y privado $^{3}$. Siendo así, en el plano narrativo de la novela son voces que representan

pescadores que pueblan la bahía de Chimbote. Elemento que obtendría sólo producto de una campal batalla entre ellos. Es cuestión ahora de generar las condiciones para que estalle el conflicto. Mientas tanto se hará de aliados y comenzará, convertido en la figura de El Viejo Tijera, a entrometerse en las fábricas y conocer los problemas para urdir el plan final. Añadamos, aparte, que este relato típico del cuento tradicional, en que las figuras arquetípicas o actantes se hallan en pleno funcionamiento, permite desde el análisis crítico, establecer relaciones de semejanzas entre estos arquetipos con los elementos que comprometen los distintos niveles presentes en la novela. En este sentido no sería un despropósito decir, por ejemplo, que el insaciable Ai-Apaec es el capitalismo, convertido en la industria pesquera; que Mellizo Marino, encarnado en El Viejo Tijera, es la burguesía representada por Marcial Quintay (Muki), el dueño de lanchas; que Yéncala, encarnada en Mara, es la libertad, el amor, aquello en disputa, el objeto del deseo; que el mar es la fábrica que es la vida; que los pescadores son los hombres y su sangre la fuerza de trabajo, su libertad; que Mellizo Terrestre es el marxismo, mediado por Dany Barrios y Pedro Chinchayán; y que Javier Balarezo, Rojitas con su grupo Los Tiburones, el profesor Villegas, el brujo, etc., así como, en otro nivel, Qué hacer, de Lenin, Cinco tesis filosófica de Mao Tse-Tung, el barrio como espacio de resistencia, los bares y prostíbulos, etc., etc., son ayudantes, obstáculos, facilitadores, positivos o negativos, con mayor o menor relevancia dentro del conflicto central interno que al final se reduce, para nosotros, en una cuestión sobre la identidad del ser chimbotano, o sea: en un problema del habitar.

${ }^{3}$ En el marco teórico que sostiene el proyecto mayor de donde este artículo es parte, afirmo que el fenómeno urbano se configura a partir de la confluencia de tres paridades básicas: campo/ciudad, público/privado y centro/periferia. La ciudad no se construye en ninguno sino en la interacción de estos mundos. En el espacio umbral, en el intersticio o derechamente en la zona de frontera es que surge realmente la ciudad latinoamericana. Como producto de un proceso dialéctico y siempre en confrontación (Chandía Araya 147). 
CATEDRAL TOMADA: Revista de crítica literaria latinoamericana / Journal of Latin American Literary Criticism Espacios, discursos y modos de habitar Chimbote en Hombres de mar (de Óscar Colchado Lucio). Hacia una tradición de la poética de la frontera chimbotana.

distintos espacios sociales pero que en su interacción configuran la de una misma comunidad. Podemos, a partir de dicha división, situar tres lugares específicos que, como universos representacionales, funcionarán cada uno como instancias privadas y que, conforme avanza el relato, se van haciendo públicas: el terreno último donde estos mundos iniciales se confunden y que, en esa confusión, hacen de Chimbote ciudad y personaje colectivo protagónico en la obra. La zona donde se construyen estos hombres de mar.

Los espacios donde confluyen estas historias son la bolichera (el barco pesquero), el Politécnico y la calle. Los dos primeros al expandirse abarcarán al conjunto de la realidad social de Chimbote y en él, la constitución y valor esencial del tercero, la calle o, mejor: la plaza pública, o sea: la Plaza de Armas de Chimbote. Así, la bolichera Flor de Chimbote, opera como núcleo central de la actividad pesquera, del mundo sindical y de las prácticas del prostibulo; en un sentido metafórico, actúa como metonimia de la principal actividad que mueve el cotidiano porteño. Luego, el colegio técnico, que reúne el mundo escolar que desarrollan estos jóvenes en una mezcla del aprendizaje formal, que surge de las experiencias en la sala de clases, con el del ambiente de barrio - la muchachada y la diversión - y en general de calle, donde, en sus primeras incursiones al ambiente sindical y prostibulario, se van a topar y confundir con el de los pescadores. La calle, por último, que, como los otros dos, se materializa en realidades concretas, en este caso en las avenidas Meiggs, Pardo y Bolognesi, el Malecón Grau y coronada por la Plaza de Armas. La pesca y el estudio técnico, la bolichera y el aula, el pescador y el estudiante, son, en consecuencia, realidades sociales distintas pero no distantes ya que están siempre en diálogo permanente y esto por dos razones fundamentales: porque para que la historia resulte deberán necesariamente encontrarse en el ágora y porque como la pesca permea toda la realidad de Chimbote, la mayoría de los jóvenes son hijos de pescadores, y cuando no, por el solo hecho de ser chimbotanos, llevan ese aire porteño proveniente del diálogo cultural entre el pasado de un pueblo pesquero y el ajetreo cosmopolita en que todas las realidades se juntan. Así, tenemos configurada la 
imagen pública de la ciudad, como espacio urbano típico, que funciona en base a estos lugares tradicionalmente determinados: el del trabajo y la producción; el de la escuela y el aprendizaje; el de la discusión y el diálogo políticos; el de la distención y la festividad; y el de la calle, que es el del encuentro/desencuentro y que termina realizándose en el de la polis, el ágora donde todos esos se hacen públicos. Si bien no aparece nombrado acá el universo opuesto del mundo privado e íntimo de la familia, sí lo está, de manera implícita, sobreentendida; de lo contrario cada una de las experiencias públicas o no se dan o es difícil que se den. La casa-familia gravita en toda esta movilidad social.

De modo que cada espacio en su funcionalidad específica, promueve un ritmo de vida que revela en su conjunto el modo de habitar el puerto. Aquello que le da su carácter distintivo como ciudad-puerto y que en la novela de Colchado queda demostrado como una realidad que construye en el cotidiano ese carácter determinante de sujeto porteño. Una identidad en relación siempre a ese modo heredado de la profunda experiencia ligada a1/la mar, como fuente dador/a, elemento vital en la supervivencia de esa comunidad pesquera. Las imágenes que surgen en la obra no se podrían dar, no tendrían sentido, no contarían con la fuerza y convencimiento suficientes, si no fuera por el oficio que mueve y da vida al puerto: la pesca de la anchoveta. Todo gira en torno a la práctica de la pesca. Nada escapa al recurso natural que ofrece dadivosamente el mar de Chimbote. El habitar por tanto impregna todos los mundos posibles que se dan en ese espacio urbano-porteño.

No es casual, por lo mismo, que Colchado use al profesor Efraín Villegas del Politécnico para que transmita a sus alumnos las Cinco tesis filosófica de Mao Tse-Tung, cuya tesis primera se llama, justamente, "De la práctica". Y antes: que Rojas Padilla haya puesto el nombre del colegio técnico en su manuscrito y que Colchado lo haya fijado en el antiguo Politécnico, cuna de ese saber práctico y más tarde revolucionario de las luchas sociales, homologable en este sentido con la sala del sindicato. En la medida que es lugar de contacto que visibiliza el 
CATEDRAL TOMADA: Revista de crítica literaria latinoamericana / Journal of Latin American Literary Criticism Espacios, discursos y modos de habitar Chimbote en Hombres de mar (de Óscar Colchado Lucio). Hacia una tradición de la poética de la frontera chimbotana.

conflicto, da adiestramiento e identifica las demandas que se harán luego públicas en las calles y en el centro del ágora, la Plaza de Armas.

Revisemos por separado cada uno de estos sitios emblemáticos para ver cómo funcionan en su cotidianeidad separada del resto. Si bien lo que les mueve y les da sentido es la pesca, mantienen no obstante cada uno un universo particular que en la novela va quedando claramente configurado. De hecho, es así como se arma el relato: desde la particularidad hacia una universalidad integradora. Como sucesos aislados que surgen en un pequeño mundo que necesariamente debe expandirse, hacerse público, legitimarse en el espacio de todos.

Como en El zorro de arriba y el zorro de abajo, como un impulso de comenzar el relato desde el principio, como la necesidad de situar los hechos a partir de un elemento ordenador, como estrategia de entrada, en fin, apropiada y convincente, es que Hombres de mar se inicia precisamente en plena faena pesquera, en alta mar, sobre la Flor de Chimbote 4 .

Desde la cubierta, junto a una de las portezuelas que dan a la sala de máquinas de la bolichera Flor de Chimbote, Pedro Chinchayán, jovencito inexperto, recién salido del colegio e incorporado al rudo trabajo de la pesca, observa absorto, en medio de la negra noche, las distintas luces

\footnotetext{
${ }^{4}$ Sin contar el Primer diario, El zorro de arriba y el zorro de abajo comienza así: "Chaucato partió en su bolichera 'Sansón I', llevando de tripulantes a sus diez pescadores, entre ellos al Maricón el Mudo [...]" (Arguedas 33). Lanchas en la bahía, de este modo: "—Cuidado. - Mucho ojo y no dormirse. - Hasta mañana. Estaba de pie en la borda de la gasolinera [...]" (Rojas 15). Y El Gaviota, así: "A las siete de la mañana los chinos marchan con sus carretillas de emoliente. Cambian los densos capotones nocturnos por uniformes cakis policíacos. El puerto comienza su vida agitada, febril, bullanguera" (Diez-Canseco 514). Más dentro o más fuera de la mar, en plena faena o entrando o saliendo de ella, en el cruce en el malecón, estos relatos -fundamentales en esta investigación- sitúan en estos espacios móviles y en acción los puntos de inicios de las historias. Podrían haber sido otros. Sin duda. Pero creo yo que hay acá el hecho de testimoniar la realidad evidente que envuelve a esos puertos retratados, que no es sino de plena actividad, de un mundo vivo y agitado. Pero también porque el narrador está dándole con esto el valor que tiene dicha actividad en el contexto porteño. Este u otro, al fin, es el mismo espacio el que se retrata. En las obras se cofunden, se hacen uno y el mismo.
} 
del puerto, sintiendo el tumultuoso vaivén de las olas que rugen con el viento (Colchado 13) $)^{5}$.

La imagen es reiterativa. Lugar común en este tipo de relatos, sin embargo, nos entrega las claves que responden al hecho de por qué esta novela aporta a la configuración de la poética de la frontera. En efecto, comenzar la historia desde la bolichera en acción, es ingresar al relato por los sentidos más que por el entendimiento ${ }^{6}$. La obra nos presenta una realidad que para ser captada en su totalidad exige aguzar los sentidos, puesto que el puerto y quienes lo trabajan, componen un cuerpo vivo de cuya materialidad emanan olores, sonidos, residuos propios de su naturaleza en proceso. La faena de la pesca por eso está marcada por la intervención del hombre en la mar, por la extracción, abundante o escasa, del producto pero también, en su ciclo natural, lo que viene después del trabajo duro y que es aquello que imagina el joven Chinchayán cuando mira a tierra y percibe las luces del puerto. "Hoy es noche de sábado y el resto de la tripulación estará [si no con su familia] tomándose unos tragos en chinganas y burdeles del puerto" (Id. 13). Como estrategia que mitiga la dureza del trabajo pesquero, aparece siempre el recuerdo de vida porteña: la última farra, un repaso a los mejores momentos, un plan de lo que se hará luego. En el fondo, la conformación de una actividad laboral sujeta a esa dinámica propia de la pesca que es más que mano de obra bruta o mecanicismo industrial, en el arte de la pesca ingresan otros mundos - como el imaginario - que no han perdido el contacto con el tiempo transhistórico, como con el inmediato, donde fluyen anhelos y recuerdos del pescador. Hay siempre en él una proyección recordatoria hacia el pasado y también desiderativa, respecto al futuro. $\mathrm{Y}$ es que no puede ser de otra manera

\footnotetext{
${ }^{5}$ Todas las citas corresponden a la edición que aquí uso: Colchado, 2011.

${ }^{6}$ Lienhard con agudeza excepcional logra interpretar episodios como estos en el estudio que realiza sobre El zorro de arriba y el zorro de abajo, de Arguedas. En el capítulo II, "La cosmogonía chimbotana. El discurso de Chaucato", da luces para entender esta cierta "teatralización de la narración", donde el uso de las "lisuras del lenguaje" resulta clave para representar escenas como las de la bolichera en acción, las voces y el léxico obsceno que envuelve todo el acto real-narrativo (Lienhard 75 y $s s$ ).
} 
CATEDRAL TOMADA: Revista de crítica literaria latinoamericana / Journal of Latin American Literary Criticism Espacios, discursos y modos de habitar Chimbote en Hombres de mar (de Óscar Colchado Lucio). Hacia una tradición de la poética de la frontera chimbotana.

para quien se gana la vida en un trabajo como la pesca (la minería o la agricultura), que además de su exigencia física, que no desconoce la muerte ${ }^{7}$, es imprevisible y fluctuante como portadora de una carga histórica que la asume, consciente o no, quien interviene la naturaleza. La pesca y estos otros son los oficios llamados primarios por ser parte de la economía primitiva y de sobrevivencia del hombre. La industrialización, aunque intenta borrar este dato, no puede contra el vínculo premoderno que existe entre el hombre y el medio natural que trabaja. El mar, la tierra, la naturaleza, mantienen siempre con quien los toca con sus manos, un vínculo de reciprocidad que es irreductible a la lógica del trabajo que impone la era industrial.

Entonces la pesca vista así, envuelve al hombre en su plenitud. Cada elemento está en función de su propósito que es la sobrevivencia y algo más. Esto funciona en la novela por medio de la representatividad que adquiere la Flor de Chimbote, en la medida que establece una relación metonímica con la pesca en particular y con la ciudad-puerto en general. La pesca, el muelle, Chimbote, son una misma realidad. Chimbote en este plano metafórico es la bolichera y la bolichera es el puerto mismo. Relación mutua que se da entre el modo de vida de a bordo con el de la vida toda en la ciudad-puerto: el trabajo, el descanso, los sueños, los triunfos y los fracasos, la abundancia y la escasez. En la Flor de Chimbote, queremos decir, se vive. Se manifiestan en ella las experiencias fundamentales del hombre de mar que son a la vez las del hombre de tierra; tierra que, preciso es decirlo, a poco andar no es más que arena del desierto, desierto a su vez que adquiere ya en esa zona las connotaciones del mundo andino.

Dentro de este plano de la memoria que surge en los momentos de distención y que podríamos decir que es donde por medio de la oralidad nace la narración (esa del fogón), la novela acude a ella como recurso impostergable. Se construye con una cuota importante de material histórico. La evocación de los

7 Respecto a la minería, notable el ejemplo de Baldomero Lillo quien plasmó la vida del minero chileno en Sub terra (1904) y Sub sole (1907). Y en cuanto al agricultor, el magistral cuento "Un hombre muerto" (1920), de Horacio Quiroga. 
pescadores fluctúa entre el exceso y el regocijo, generados por el boom de la pesca, y la falta y la penuria, debido a su caída en picada. Siempre está ese tiempo mejor que ocupa el momento presente.

Qué diferente cuando estaba el finadito Bianchi Ross [que en la realidad es Luis Banchero Rossi, pionero en la industria pesquera]. Él sí cualquier cosa que había la celebraba con todos nosotros. Ponía trago, comida, buena música y hasta mujeres. Con él no había diferencias. Pero ahora los obreros no somos nadie... [...] Catay, por estos años del 2000 sí que la pesca se ha puesto bien jodida. El mar ya no es más la hembra paridora de antes. Ahora pare cocaína en vez de anchoveta (Colchado 15-17).

Lo que nos revela este pasaje de a bordo es que hay nostalgia del pasado y crítica del presente. $\mathrm{Y}$ en esa zona de frontera temporal se erige el relato. No para quedarse en ese pasado improductivo, aunque sí tomándolo siempre como referente vital, sino como impulso para mejorar el presente. Hombres de mar no es la historia del esplendor, como de cierto modo lo es Los zorros de Arguedas cuyo tema no es la riqueza pero sí las causas y sobre todo las consecuencias que ella produjo-, ni tampoco la del fracaso; es, mejor, la historia del proceso del cambio, del quiebre, del gran proyecto por hacer. La obra que estudiamos es la novela de la crisis y de la utopía. Un lapso de tiempo que en Chimbote va del posboom de la pesca al terreno de las luchas y reivindicaciones sociales que se producirán en toda la región, con esa cuota de sangre que sus impulsores ni en sueños imaginaron, para terminar en el 2000 en un clima de desencanto generalizado, en una región absorbida ya por la economía de libre mercado que bajaba de manera irrefrenable del norte hacia todos los rincones de América del Sur.

Por eso que es crucial entender el rol que juegan aquí la bolichera, el colegio técnico y la calle, como espacios sociales en construcción, porque será en estos escenarios donde se fraguan los hechos que definen la historia de la novela. 
CATEDRAL TOMADA: Revista de crítica literaria latinoamericana / Journal of Latin American Literary Criticism Espacios, discursos y modos de habitar Chimbote en Hombres de mar (de Óscar Colchado Lucio). Hacia una tradición de la poética de la frontera chimbotana.

El rol de pescador de Pedro Chinchayán es básico para el desarrollo narrativo. $\mathrm{Su}$ debut y crecimiento en la Flor de Chimbote - que puede leerse como propio de la novela de formación o Bildungsroman - cumple una doble función: de un lado, evidencia el rigor del trabajo, y por tanto un aprendizaje práctico y vital, y de otro, inculca en el muchacho el espíritu crítico y el anhelo de justicia. Legitima en el fondo su actuar político-sindical; el que nace del contacto directo con la realidad que reclama. Pareciera que para Colchado la relación con la práctica es fundamental para el desarrollo pleno de sus personajes. Lo que por cierto pone en cuestión el modo de hacer política de los grupos de poder que se explayarán desde entonces a lo largo y ancho en toda la región. Una política de tecnócratas, funcionarios de escritorio que del mundo real y concreto saben poco y nada. El asunto sindical que la novela incorpora y que funciona como uno de los hilos conductores en la obra, hace de ella testimonio que visibiliza un hecho decisivo en el referente histórico que reconstruye. Los sucesos en torno al movimiento sindical en Chimbote le asignan al testimonio y por tanto a la novela la dimensión política insustituible para narrar los hechos de una realidad marcada fuertemente por un afán hegemónico a nivel económico, social y cultural. Hombres de mar asume un discurso y una clara postura respecto a la cuestión del poder, por eso no puede la obra de Colchado leerse sin este componente elemental que la sitúa como un producto además de estético, ideológico (y también didácticoformativo). Elementos que hacen que estemos así ante un bien social que entretiene, enseña y juzga, ética, valóricamente.

De modo que el joven Pedro Chinchayán será quien encarne en este contexto de la narración la figura del ser político, cuya validez se legitima porque su actuar está presente tanto en la pesca como en el sindicato, en las bases como en la dirigencia política. Una suerte de Che Guevara mezclado con el paradigma del intelectual orgánico de Gramsci; modelos por lo demás presentes en los años 
de lucha social en las izquierdas latinoamericanas ${ }^{8}$. Destacan en el joven la coherencia, la entereza y la consecuencia con las que entrelaza praxis y teoría. Cuando unos alumnos, que trabajan para un diario escolar, le preguntan al profesor Villegas si conoce a Pedro Chinchayán, éste, un poco esquivo les responde: "Este... sí, claro, fue mi alumno en el Colegio San Pedro, tres o cuatro años atrás. Terminando la secundaria se metió a pescador. Ahora es un gran líder sindicalista [...] cuadro importante de una facción de la izquierda peruana" (Colchado 33-34). Estudiante, pescador, sindicalista..., la trayectoria ideal del líder para la conducción de cualquier proyecto reivindicativo, como la huelga de los pescadores. El reconocimiento popular de Chinchayán queda no obstante ratificado frente a sus pares, en la Flor de Chimbote. En plena faena de pronto la hélice de la bolichera se atasca con un paño, trozo de tela de la vela que impide que avance. Como nadie se atrevió a sumergirse — ni por los dos mil soles que el capataz ofrecía-, Chinchayán fue el único que levantó la mano. Se untó el cuerpo con grasa y saltó a las gélidas aguas. Después de algunos percances (se corta la mano) emerge heroico, liberando la nave y de paso aprobando con creces su prueba inaugural. $\mathrm{Su}$ bautizo. "Ya eres uno de los nuestros, huevonazo" (Id. 39-42), le bromean sus nuevos camaradas.

Sin embargo el demostrado entusiasmo y destreza de Chinchayán como prominente pescador es una parte; la otra, y que tendrá mayor desenvolvimiento en la novela, es la del sindicalista. Encarna la figura egregia del dirigente sindical que el marxismo clásico propugna y promueve. Chinchayán es el cuadro que distribuye su trabajo político en las distintas áreas de la estructura revolucionaria, tanto a nivel práctico como teórico-político. Como vimos, es un pescador hábil,

${ }^{8}$ En Arguedas / Vargas Llosa. Dilemas y ensamblajes, un análisis crítico de Mabel Moraña en que estudia las convergencias y divergencias intelectuales, estéticas e ideológicas de estas dos últimas principales figuras del Perú, sitúa al primero como representante alternativo - "la imagen en negativo"- del intelectual orgánico, cuyo éxito se apoya en la complicidad con el poder. En tanto que Vargas Llosa sería el intelectual criollo. "Como intelectual criollo, urbano y consustanciado con los procesos de institucionalización cultural, dentro y fuera del país" (Moraña 24). En la novela si bien usamos a Chinchayán para emular la figura del intelectual orgánico, tendrá que verse siempre complementada y respaldada por Dany Barrios, líder sindical y lector de Lenin, y por el profesor Villegas, maestro de Historia en el Politécnico y que instruye a sus alumnos en la doctrina maoísta. 
CATEDRAL TOMADA: Revista de crítica literaria latinoamericana / Journal of Latin American Literary Criticism Espacios, discursos y modos de habitar Chimbote en Hombres de mar (de Óscar Colchado Lucio). Hacia una tradición de la poética de la frontera chimbotana.

pero también ejecuta labores de propaganda, organización y adoctrinamiento político que, en poco tiempo, lo llevarán a convertirse en sujeto peligroso para la dictadura, la que a través de sus órganos represivos lo perseguirá para encerrarlo. Razón por la cual no le queda otra que pasar a la clandestinidad, pero pronto la policía lo descubre, lo apresa y se lo lleva a Lima secuestrado. En el trayecto, en

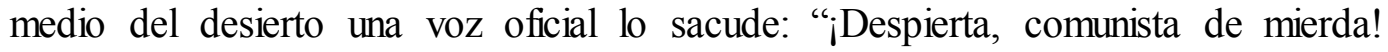
¡Acaban de botarlo a Allende en Chile!” (Colchado 174). Es el 11 de septiembre de 1973. Secuestrado y torturado por varios días en Lima logra, gracias a las gestiones de su padre y a la intervención de un juez, salir en libertad. Este hecho lejos de aplacarlo refuerza aún más su compromiso con los pescadores.

Así, transcurren algunos años hasta que la situación se va tornando cada vez más difícil. La causa principal detrás del conflicto está en que las empresas que Velasco Alvarado en su gobierno había expropiado a los privados, con las cuales creó la estatal PescaPerú, ahora el golpista Morales Bermúdez, en una estrategia claramente antidemocrática y procapitalista, bajo el subterfugio de las “pequeñas empresas cooperativistas", planea devolvérselas (Colchado 225). Injusticia que hará que el conflicto pase de un problema sindical cualquiera a uno de carácter nacional, generando un clima tenso entre los trabajadores y el gobierno central. Con esto el rol de Chinchayán se activa y, por seguridad, pasará, por segunda vez, a la clandestinidad. Oculto en casas de amigos y consciente del peligro que corre, decide reforzar todavía más su seguridad manteniéndose por esos días de agitación en absoluto secreto. Toda vez también que esta condición suya va creando en él el mito, la leyenda del joven insurgente.

Tanto es así que ya en el calabozo en Lima, Pocho, que es detenido por traficar droga9 ${ }^{9}$, le pregunta: "Tú eres de Chimbote, ¿no es cierto? [...] ¿Qué sabes

\footnotetext{
9 Hay aquí un episodio que vale rescatar. Este Pocho, un pituco, un blanquiñoso, consumidor y traficante de pasta base y marihuana, entonces novio de Lily, quiere expandir su mercado al barrio de Los Tiburones, donde viven los jóvenes del Politécnico. Pero estos no están de acuerdo, por lo que han planeado un duelo entre Pocho y el líder del barrio, el Gordo Grados, que también pretende a Lily. Si Pocho gana se queda con Lily y con las calles del barrio para traficar, pero si pierde Lily es de el Gordo y no debe aparecerse más por el barrio. La pelea que se lleva a cabo en
} 
de mí? Ah, pues, de tu participación en las huelgas, si eres bien famoso allá, cómo no voy a saber de ti" (Colchado 175). Y más tarde, cuando el conflicto sindical se torna fenómeno público, se nos dice: “Chinchayán goza de la admiración de las mujeres. Es joven, de porte atlético, bien parecido y, sobre todo, muy carismático [aparece con frecuencia en la prensa local]" (Id. 232). Esta misma fama traslada a la figura de Chinchayán al plano erótico. Lo ubica en una situación distinta que no se condice, en general, con la imagen típica del líder político que el marxismo duro impone. No caben aquí sentimentalismos ni deseos carnales (Chinchayán si va a los prostíbulos lo hace siempre en calidad de dirigente: no bebe, no se aparea con las putas) considerados débiles por vanidosos y evasivos. En esta política pura y dura no hay espacio ni tiempo para asuntos individuales. El principio y fin de la lucha debe estar puesto en derrocar al Estado burgués para instalar el del proletariado. Toda acción que no vaya en esa dirección es un impedimento y por tanto enemiga de la revolución. Esta es más o menos la lógica que estaba o debía estar operando en el interior del joven Pedro Chinchayán. Pero no, Colchado lo conflictúa, lo lleva a situaciones límites, lo coloca en la frontera, porque para eso está la literatura: para romper estos moldes y poner en tensión el deber ser con las pasiones del cuerpo de mujeres y hombres; para enfrentar en suma el discurso con la realidad. Lo cierto es que Chinchayán es un joven que está en peligro, que conforme se agudiza la huelga de pescadores su vida entra en una situación de extremo cuidado: lo buscan para matarlo. Esto lo obliga a sumergirse aún más en la clandestinidad, a reforzar su cuidado y a cambiar constantemente de escondite. En esta condición de prófugo con cierta distancia pero siempre ayudándole, está La Toya Otárola, hija de un compañero sindicalista. De modo que toda esta

la playa de Miramar va en serio, con cuchillas (chavetas). Después de un par de golpes e improperios, finalmente vence el Gordo Grados. La pelea, rito común por cierto en estas lógicas de iniciación-apropiación de las pandillas, que termina por consolidar el predominio absoluto de Los Tiburones sobre el barrio, define también una postura clara respecto a la droga. Un guiño valórico sin duda del narrador para establecer una mirada respecto a lo que fue para esa generación más que la marihuana la pasta base y la cocaína. Rechazo al fenómeno que recién y de a poco estaba ingresando a las poblaciones y que entonces era imposible de prever los daños que iba a generar en los más pobres. En la pelea, le dice Pocho a su rival: "Las huevas que te vas a quedar con Lily, so cojudo. Y yo le respondí que Lily no me interesaba ya, pero sí mi barrio, su gente, y que ningún hijo “e puta entraría para intoxicarla” (Colchado 272). 
CATEDRAL TOMADA: Revista de crítica literaria latinoamericana / Journal of Latin American Literary Criticism Espacios, discursos y modos de habitar Chimbote en Hombres de mar (de Óscar Colchado Lucio). Hacia una tradición de la poética de la frontera chimbotana.

situación forzada que enfrentan los muchachos derivará en episodio erótico, en la consumación del acto sexual, como instancia de transgresión y reivindicación humana.

Confluyen aquí dos realidades que lejos de repelerse inscribirán la parte más erótica de la novela y sin duda alguna uno de los pasajes narrativos mejor logrados. Los elementos juegan todos a favor. De un lado está Chinchayán, el animal fugitivo que huye de su cazador y para quien la belleza femenina y sensual de La Toya - tan extraña a ese estado cavernario de sobrevivencia en que se halla- es un deseo carnal irreprimible. Y de otro lado está ella toda. La muchacha que lo admira y lo desea; que entra a sus guaridas "con su fresca piel, sus labios sensuales [vestida con] una fina blusa delgada, ceñida, que resalta sus hermosos senos adolescentes, y una ajustada falda de jean que aprisiona sus anchas caderas y deja ver sus torneadas piernas" (Colchado 232, 318). Pese a lo evidente no es tan fácil sin embargo la realización del enlace sexual, ya que gravitan acá principios ético-ideológicos que entraban y retardan los impulsos del incorruptible Chinchayán.

¿No me amas? [le pregunta Toya] Justamente si quiero que te vayas [le responde él, evitando siempre mirarle su cuerpo] es porque eres una gran tentación. No quiero enamorarme de ti. ¿Y por qué no quieres enamorare de mí? No sólo de ti — dice él—, de ninguna mujer. ¿No te gustan las mujeres? Me encantan. ¿Y entonces? Simplemente porque no tengo tiempo para dedicarle al amor (Id. 319).

Luego de una serie de excusas en que intenta convencerla/se de lo inapropiado que resulta enamorarse de un combatiente, cuya vida está siempre en peligro de muerte, etc., no puede empero el animal político contra el animal carnal. Y así entre declaraciones de amor "le arranca la fina prenda que le cubre el 
sexo y furioso introduce su miembro una y varias veces haciéndola gemir" (Id. $320)$.

El valor que tiene la escena sexual en el meollo de la novela es doble y complementario. El primero corresponde al plano estético, ya que por la forma en que se disponen una serie de recursos narrativos, una suerte imaginería erótica, hacen del acto un hecho de indudable carga simbólica. El segundo al ético. Al poner a Chinchayán en un estado sexual-erótico se abre al mismo tiempo la dimensión política a un carácter más integral que termina humanizándola. Erotiza y sensibiliza la actividad de la polis, trastoca la res publica, conecta lo irracional con el de la ratio por excelencia. Y por cierto, también, en este juego de reciprocidades, instala el amor en medio de la cuestión pública, pone la alcoba en el ágora misma, legitimando así el cuerpo y sus deseos como derecho de todos. En síntesis, al traspasar las barreras de lo público y lo privado, se entra a un espacio otro, una zona de frontera que permite desarrollar prácticas o modos de relacionamientos alternativos que resisten las lógicas impuestas y a su vez proponen la incorporación del hombre en su plenitud. Infringe así la novela de Colchado a través de este episodio, los límites que han regido tradicionalmente los compartimentos que separan la política del amor y de paso ofrece un relato que trasciende, rejuvenecido y vital, a la producción de la literaria peruana del siglo XXI.

Acontecimientos como este, en que la dimensión política se fusiona con lo afectivo-sentimental, haciendo de ambas instancias porosas que en su movilidad transformativa permean la unidad de la novela, no son, creemos, hechos aislados o fortuitos que no estén de alguna manera formulados en el proyecto narrativo de su autor. Si existe el intento de configurar una novela que aborde en su totalidad el referente elegido, entrecruzamientos, rupturas y asociaciones, serán pues situaciones ineludibles a lo largo de la trama narrativa. De modo que las partes pero sobre todo el conjunto de la obra puede leerse como el resultado de múltiples contactos-contagios. Un hecho que la ubica también, aparte de la realidad que retrata, en un espacio de frontera. No sólo Chimbote, la ciudad-puerto, responde a 
la noción de frontera, como espacio del habitar, sino también el discurso que la recrea, el que se hace, como dice Cornejo Polar, para dar cuenta precisamente de ese fenómeno en su totalidad, heterogéneo. Una realidad heterogénea como esta no puede o no logra construirse a partir de un lenguaje homogéneo, ya que las partes que describe responden a un universo eminentemente heterogéneo, es decir, a una naturaleza compleja y múltiple que exige ser enunciada en un lenguaje igual de complejo y múltiple. Esta es la fórmula que el crítico peruano ofrece (en su momento para comprender críticamente la literatura indigenista pero que luego queda comprobado que es aplicable al estudio de otros discursos de la narrativa latinoamericana — como modelos referenciales Arguedas y García Márquez, de un producto heterogéneo, y Vargas Llosa y Donoso, de uno homogéneo-) con el propósito de abordar ese desajuste o contradicción dentro del proceso de producción: el de la heterogeneidad no-dialéctica. O sea, el de un esfuerzo reflexivo-creativo, en el discurso estético-literario, que asuma la multiplicidad como constitutiva de la realidad y que no cierre, que no acabe, según el modelo dialéctico, en síntesis: en un resultado procesal, sino en un espacio donde los extremos "no solamente se tocan sino que intrincadamente se entrecruzan en imaginarios abigarrados y tensos" (Moraña 77) ${ }^{10}$. En este sentido, Hombres de mar, por lo que venimos diciendo respecto a su posesionamiento ineluctable ante la compleja realidad que retrata, resulta una novela cuyo texto queda abierto, inacabado, irresuelto, que la hace un producto estético-social en permanente

\footnotetext{
${ }^{10}$ La noción de heterogeneidad busca así tomar distancia (zafarse del cepo) de lo "que impone el falso imperativo de definir en bloque, de una vez y para siempre, lo que somos: una identidad coherente y uniforme, complaciente y desproblematizada (la ideología del mestizaje sería un buen ejemplo), que tiene que ver más con la metafísica que con la sociedad y la historia" (Cornejo Polar, Escribir 13). Todo lo cual demuestra que tanto la noción de hibridez pero sobre todo la de mestizaje, en su aplicación, parece no ser capaz de dar cuenta de la complejidad del conflicto, demuestra haber "agotado casi toda su capacidad iluminadora" y, en consecuencia, esta incompatibilidad supone en el uso el frágil intento de sintetizar en un espacio de resolución armónica el conflicto. De ser parte de la solución pasa a ser parte del problema (Cornejo Polar, "Una heterogeneidad" 838 y ss.). Así, asumido ya el compromiso por la heterogeneidad, haciendo un balance entre un primer momento en que el crítico peruano detecta el fenómeno dentro de los procesos de producción y un segundo momento en que, declara: "Entendí más tarde que la heterogeneidad se infiltraba en la configuración interna de cada una de esas instancias, haciéndolas dispersas, quebradizas, inestables, contradictorias y heteróclitas dentro de sus propios límites" (Cornejo Polar, Sobre 71 y ss., Escribir 10).
} 
autoconstrucción cultural y que, por tanto, no puede sino analizarse críticamente a la luz de la teoría que ofrece el estudioso peruano.

Entonces en esta lógica de interacciones mutuas en que nada se agota en sí mismo, en que todo se hace en y con el otro, de manera relacional: la pesca, materializada en la Flor de Chimbote; la política militante, personificada en Pedro Chinchayán; el aprendizaje juvenil que simboliza la escuela técnica y que encarna Rojitas, no pueden leerse - ni los lugares, ni las acciones, ni quienes los ocupan y ejecutan- como individualidades, sino como partes de una estructura social que es la comunidad de Chimbote. No cabe aquí la idea del fragmento o entes aislados de un conjunto autónomo. Las fuerzas que los mueven al contrario responden a estrategias de poder y resistencia. La dictadura, la empresa privada, la organización sindical, la lujuria prostibularia, los lazos de amistad en el barrio, etc., son todos impulsos que pugnan por ganar su espacio dentro del conjunto social $^{11}$. De modo tal que la pesca, en este sentido, contiene un valor doble, contradictorio y en tensión. Por un lado, representa de manera inequívoca el éxito de la industria y el capital a gran escala, donde en esa bonanza el pescador vale en la medida y sólo en la medida de su fuerza bruta, por lo tanto, sustituible y prescindible, porque su historia individual y colectiva no cuentan. Por otro lado, la pesca es una actividad cultural que compromete al hombre en su totalidad y que en su plenitud involucra otros espacios sociales, como el prostibulo. Pesca y puterío mantienen un trato sagrado inclaudicable, el que se expande a la bebida, a la comida y en general a la fiesta. Por lo mismo la figura del pescador Chinchayán debe verse también en esta otra dimensión - y si no él mismo, pues el colectivo a quien representa- La hazaña que mostró al desentrabar la bolichera, su fuerza,

11 Esto nos lleva a extender las ideas de Bourdieu. La literatura y en general la producción artística, están afectas a una autonomía relativa entre ella y su creador. En este carácter de interdependencia aparecen condicionantes que van a intervenir en el proceso de producción dentro del campo intelectual. Ya que dentro del mismo van a comenzar a actuar valores, axiomas, por parte de una incipiente crítica, también relativamente autónoma. Lo que evidencia que este espacio se transforma en un campo de lucha por el poder y por la legitimidad cultural. Cada grupo o agente que interviene, intentará, ya sea por su poder o por la posición que en él ocupa, integrarse al sistema validando su producto cultural (Bourdieu 9). 
CATEDRAL TOMADA: Revista de crítica literaria latinoamericana / Journal of Latin American Literary Criticism Espacios, discursos y modos de habitar Chimbote en Hombres de mar (de Óscar Colchado Lucio). Hacia una tradición de la poética de la frontera chimbotana.

su espíritu laborioso debe, en esta lógica popular, necesariamente complementarse en el prostibulo.

Prostíbulo que a su vez es más que el puro acto sexual. Aglutina una serie de prácticas, donde el sexo, acto principal, el alcohol y la comida, todo dentro de un exacerbado goce corporal asequible con el despilfarro del dinero fresco de la pesca, es una afirmación propia de una identidad cultural de carácter popular. Una manifestación marginal y suburbial bastante estudiada ya en la literatura y en las ciencias sociales. La prostitución de los puertos, desde la superficialidad con que suele leerse, resulta un fenómeno, cuando no censurable o victimizado a favor de la mujer, pintoresco. En general, un modo de diversión, transgresión o iniciación (veremos a Rojitas) donde se mide la supuesta hombría de sus concurrentes; y los estudios de género, por su parte, a veces por no verlo desde un plano cultural más abarcador, terminan zanjándolo, sin más, bajo el sello del machismo, que sin duda lo hay ${ }^{12}$. En cambio, si lo vemos con más detenimiento y desde la mirada totalizadora que venimos empleando, nos damos cuenta que responde a un modo de ser que en la cosmovisión popular entiende la vida de manera práctica, ligada a lo material inmediato y esencialmente a través del cuerpo. El exotismo superficial oculta lamentablemente una filosofía vital propia del sujeto popular.

En un contexto similar, cuando Muki, patrón y dueño de lanchas partía recién con su negocio — que más tarde derivará en narcotráfico-, les ofrece a los pescadores asociarse, la respuesta que ellos dan define su identidad y por tanto sus límites y potencialidades frente al mundo moderno: "Es que a los pescadores no nos gusta endeudarnos, Muki. Lo que a nosotros nos vacila es chambear y tener billete para chupar, ir al estadio, al chongo... tu sabes" (Colchado 87). A eso se puede reducir la esencia del pescador. A una personalidad que por un lado mantiene una distancia respecto a la lógica moderna, en concreto al embrollo

12 Tiene no obstante una resonancia mayor dentro de las lógicas del mundo popular. El mejor feminismo ha visto en la prostitución una de las mayores injusticias y aprovechamiento contra la mujer, contra la mujer pobre, y negra, por supuesto; pero a su vez también una instancia de liberación, de un oficio donde ella no siempre ha estado obligada a ejercerlo sino que como práctica voluntaria de emancipación económica y vital. 
mercantil, renuente al endeudamiento, y por lo mismo a una relación de inmediatez con el dinero (lo que se gana se gasta, no se invierte, no se guarda; se derrocha; se comparte). Como una suerte de principio ético de que lo que se consigue con esfuerzo se despilfarra con jolgorio. Y por otro, por lo mismo, a un apego a la materialidad de las cosas, en cuanto objeto de uso, de consumo desechable, en que si no se utiliza no sirve. Equilibrio vital del saber popular donde el dinero es siempre y no más que el medio metálico necesario para la sobrevivencia y el placer. No hay aquí especulación, inversión, reserva o acaparamiento. Hay por el contrario una experiencia con la materialidad inmediata, abierta a un presente absoluto y gozador ${ }^{13}$.

Esa distancia, esa desconfianza frente a la modernidad si bien marca un grado de libertad no obstante es también causa de una pobreza histórica. La paradoja de la clase trabajadora, la disyuntiva entre modernidad/tradición. Es decir el quid de la transculturación y la perentoria estrategia de la solución intermedia que deberá asumir más temprano que tarde el serrano ${ }^{14}$. De lo que se trata pues es de una cuestión de equilibrio. No podemos hacer una apología de la pobreza ni desconocer los males (alcoholismo, drogadicción, violencia familiar) que afecta y somete históricamente a la clase trabajadora, pero tampoco podemos seguirle el juego a la lógica del capital burgués, quitándole al pobre su derecho irrenunciable al esparcimiento; controlando sus conductas, vigilando, reprimiendo, desnaturalizando ese apego ancestral suyo a la fiesta, a la comida y al alcohol. Y no sólo la burguesía: el marxismo ortodoxo también veía en la fiesta un obstáculo casi imposible de superar. La diferencia es que mientras los dueños

\footnotetext{
13 Esto resulta clave para entender la diferencia entre la cultura popular y la cultura de masas. Mientras esta última se construye en el consumismo, en que desde la masificación de la mercancía desechable va a erigir su cultura-identidad, el mundo popular, al revés, y por su larga historia, no sólo no se construye en el consumismo sino en un consumo que, como sujetos urbanos, les resulta inevitable, y con el cual mantendrán una relación siempre tensa, crítica y de resistencia. Gastar en fiestas, como sea, sigue siendo un modo de consumo más que de consumis mo.

14 "La modernidad no es renunciable y negarse a ella es suicida; lo es también renunciar a sí mismo para aceptarla" (Rama 28 y ss.). El tema es bastante conocido ya y en sus orígenes modernos, imprescindible Fernando Ortiz, Contrapunteo cubano del tabaco y el azúcar (La Habana, 1940).
} 
CATEDRAL TOMADA: Revista de crítica literaria latinoamericana / Journal of Latin American Literary Criticism Espacios, discursos y modos de habitar Chimbote en Hombres de mar (de Óscar Colchado Lucio). Hacia una tradición de la poética de la frontera chimbotana.

del capital entienden la borrachera como rival, una traba que hacía que el obrero produjera menos y en consecuencia generara menos riqueza, para el sindicalismo marxista en cambio la jarana alienaba, no generaba consciencia de clase ni interés por la organización y por tanto mantenía la sujeción, la dependencia, el semiesclavismo.

La cuota de irracionalidad del burdel no se aviene, así, al modelo del obrero eficiente ni al del hombre nuevo del marxismo; ni, por supuesto, al del verdadero cristiano que propugna la Iglesia Católica, cuyas prácticas tilda de inmorales, pecaminosas, donde el prostíbulo es el Infierno mismo. ¿Cómo entender pues esta costumbre de los pescadores de Chimbote que una vez terminada la faena ingresaban para no salir hasta el otro día — derrotados - de los puteríos que les dejaba sólo, y acaso, con lo puesto? ¿Cómo leer esto sin caer en extremos condenatorios que lo que revelan es una absoluta ignorancia ante costumbres que por siglos vienen reproduciendo las culturales populares? Recuperando, qué duda cabe, la dimensión cultural de estas sociedades que el determinismo economicista, que funciona para uno y otro lado, niega, pasa por alto, subestima. El enfoque culturalista permite ver acá, en estas prácticas comunitarias, un espacio de resistencia y transgresión, un reencuentro con el pasado, con el mundo mágico-religioso y con el presente mismo en que reafirman sus lazos afectivos, el sentido alegre de la vida; todas experiencias colectivas de las que extraen las fuerzas para resignificarse y así enfrentar las condiciones, que a pesar de la riqueza pasajera de la pesca, son generalmente adversas. Sin embrago el mundo popular no sólo tiene que luchar contra esa pobreza perenne que le acecha, sino también con la pérdida de sus valores. A la subproletarización se le suma la amenaza del estancamiento de su cultura. La negación y el ocultamiento van de la mano con su pobreza y esto porque no ha podido, en esas condiciones, capitalizar sus saberes y prácticas. Ni el arte ni menos las políticas centrales han favorecido su movilización y por tanto ha ido quedando si no relegado, como pieza del folclor nacional que las elites usan como patrimonio negociable. Con todo, el mundo popular no decae, desde la resistencia permanente 
o desde la ruina inminente, da la lucha por sobrevivir ante los múltiples aplacamientos.

No podemos ver por eso el asunto de la prostitución en este puerto, ni en todos los puertos y ciudades de la región, desde el sesgo económico o político, solamente; precisa de la integración que otorga la mirada cultural, que concibe al hombre en todos sus planos, en su totalidad, compleja y contradictoria. En el caso de los pescadores de Chimbote, lo que significa el conflicto que genera la coexistencia de múltiples realidades: la vida loca que crea el dinero fácil de la industria pesquera, el cosmopolitismo que llega para quedarse y los indígenas que bajan de la sierra; todo lo cual creará ese hervidero que va a transformar para siempre este que fue el puerto pesquero más grande del mundo.

Entonces, volviendo a la novela, habría, por lo mismo, en la figura de Chinchayán, en comparación con sus colegas, una brecha que ubica a unos y a otros en realidades distintas ${ }^{15}$. Sin ser los pescadores en general rompehuelgas no

15 Pedro Chinchayán es sin duda alguna el personaje más político de la novela. Cumple el perfil del sujeto político que ha llegado a encarnar el dogma marxista de la conciencia de clase (de sí y para sí) que el momento histórico social que la obra recrea necesita en su carácter políticoideológico. Reaparecerá por cierto a lo largo del relato pero siempre en esta condición suya de perseguido y finalmente preso. Después de su primera detención y posterior conducción a Lima, más tarde y por delación, volverá a pasar por lo mismo. Ya libre y luego de estar internado en la sierra al interior de Chimbote, es vuelto a capturar y acusado de ser un líder de Sendero Luminoso. Se le imputan unos atentados, se le tortura ("para contrarrestar el dolor físico, se mentaliza") pero al final y gracias a gestiones oficiales se le libera, arguyendo que en verdad nada tiene que ver con Sendero, que "Terruco" no es (Colchado 446-447). Termina de algún modo su participación en el momento presente. En las últimas páginas nos encontramos con un Pedro Chinchayán que visitando la tumba de su padre, reflexiona sobre su pasado, a modo de balance y liquidación de lo que había sido su historia y la de los suyos. Da cuenta del momento que vivió como militante, de la situación actual de la izquierda peruana, de los caídos en la gran huelga (como Mariela -cuyo cuerpo nunca fue hallado- y Gordo Grados), en fin: de la derrota, los sueños, las ilusiones de una generación de la que él era un sobreviviente. El narrador se explaya aquí contando más detalles de Chinchayán. Se sabe que proviene de Conchucos, poblado serrano próximo a Chimbote, y de su llegada al puerto, siendo muy joven. Una suerte de microrrelato que permite imaginar ese viaje iniciático sierra-costa. Los acercamientos de los poblados originarios, la figura del viaje en tren, la llegada a la ciudad y todo ese imaginario del asombro y del descubrimiento propio de nuestra moderna urbanización regional. Por el modo en que se cuenta, da la impresión de la necesidad de parte del narrador de plasmar la biografía de un personaje histórico real, de saldar una deuda histórica pendiente. Excesos de detalles y forzamientos en el recuerdo conducen a establecer la existencia más real que ficticia de Pedro Chinchayán, pero sobre todo de cientos y miles de serranos (Colchado entre otros) que dejaron un día su tierra para arrimarse a esa modernidad que la costa peruana les estaba ofreciendo (Colchado 485-488). En "El tren" (Del mar a la ciudad, 
CATEDRAL Tomada: Revista de crítica literaria latinoamericana / Journal of Latin American Literary Criticism Espacios, discursos y modos de habitar Chimbote en Hombres de mar (de Óscar Colchado Lucio). Hacia una tradición de la poética de la frontera chimbotana.

simpatizan siempre con este tipo de actividades sindicales porque, como dice uno de ellos, lo suyo está en otra parte, en la secuencia: pesca, plata, alcohol, fútbol, putas... pesca, plata... un círculo vicioso ${ }^{16}$. No obstante la historia ha demostrado que llegado el momento la clase trabajadora se moviliza poniendo a prueba su verdadero poder revolucionario. Es cuando precisamente a partir de paros, huelgas y violentos enfrentamientos, con su cuota importante de muerte y pérdidas de todo tipo, se producen las transformaciones que marcan el proceso histórico de nuestras sociedades. Las horas de trabajo, los contratos, los derechos de la mujer, la salud, el trabajo infantil, no han sido jamás fruto de un altruismo aristocrático; son el resultado de largas y duras batallas que han debido afrontar los trabajadores no sin el sacrifico y la sangre derramada. La huelga de los pescadores de Chimbote, como fenómeno social estructural en Hombres de mar, busca rescatar justamente este espíritu de insurrección latente en los habitantes del puerto $^{17}$. Un proceso que va de menos a más, que comienza en unos pocos y que se propaga e integra en la plaza pública a toda la población, como expresión límite del conflicto.

En este ambiente aparece, para no dejar nunca de estar presente a lo largo de la novela: "una mujer delgada, de tez clara, facciones agradables, ya con la juventud marchita y vestida con humildad. Es Sara Sarandonga, "exbailarina venida a menos, pero muy estimada como luchadora social [...] que andaría arriba de los cuarenta años, se le notaba todavía ese aire farandulero que se le había quedado de sus tiempos de bailarina de night club" (Colchado 69, 456). Chalaca de nacimiento, llega al puerto en la oleada de la anchoveta. "Allí — le cuenta una

1981), cuento fantástico, Colchado ilustra este experiencia del viaje de la bajada de los Andes al mar.

16 Esta dicotomía no es nueva. Aparece ya en Lanchas en la bahía representado por Rucio del Norte y Alejandro. Mientras Alejandro es militante activo del sindicato, Rucio si bien se mantiene empático y en absoluta solidaridad con la causa sindical, lo suyo está en otra parte. "¿Al Sindicato? - le responde a su colega cuando lo invita-. ¿A qué? ¿A oír hablar leseras? Compañero aquí, compañero allá, y de ahí no salen. Mejor me voy a dormir” (Rojas 59).

${ }^{17}$ Fue en 1960 el año de la histórica huelga de los pescadores de Chimbote. Después de 83 días de paro se llegó finalmente a un acuerdo entre los pescadores y los armadores e industriales pesqueros. Los hombres de mar recibirían el $22.40 \%$ por tonelada de pescado extraído. 
amiga - la plata está botada, hija. Los pescadores se dan el lujo hasta de quemar billete" (Id. 75). La noche chimbotana y el contacto con el mundo de la pesca hacen de esta bailarina la mentora, especie de madrina del movimiento sindical. Fue ahí, dice, haciendo un repaso a sus años de diva nocturna, que le vino la idea: "iClaro!, me dije, eso es justamente lo que yo debo hacer: apoyar a los trabajadores en sus luchas. Esa sería mi misión en adelante" (Id. 77). Y es así como asume ese rol y la de figura infaltable en cuanto a reuniones y actividades sindicales se refiere. La relación (que no es más que una mera y atractiva coincidencia, más aún cuando me consta que Colchado desconoce la obra de Bolaño) de Sara Sarandonga con Auxilio Lacouture, de Amuleto (1999), de Roberto Bolaño, salta a la vista. Coinciden, además del físico (Auxilio, mujer de alrededor de cuarenta años, alta, delgada), en su condición de foráneas: una uruguaya, la otra del Callao; pero por sobre todo por la función que tienen como protectoras o custodios de la memoria histórica de una generación huérfana por la tragedia sociopolítica de los setenta. La presencia de Sara Sarandonga - no tan explícita como la de Auxilio, la que además en la novela de Bolaño asume la voz de narrador-testigo presencial de los hechos ${ }^{18}$ — es relevante puesto que tanto por sus años de experiencia en el ambiente como por ser bailarina y no ejercer nunca, según ella, la prostitución, le dan un cierto rango neutral y objetivo en ese clima de decisiones y toma de acuerdos políticos. Sin embargo no son sólo los años sino también el vivir-ambos-Chimbote. El que la recibe joven, con billetes usados como cerilla o papel higiénico, según cuentan, y el que habita en el momento presente, el de la crisis e injusticias sociales. Sara, como Auxilio, encarna así la experiencia que se legitima en sabiduría. El capital que ofrece en situaciones

\footnotetext{
18 La novela está ambientada en el contexto de lo sucedido el 18 de septiembre de 1968 en la Ciudad Universitaria de la UNAM, México, que precedió a la Matanza de Tlatelolco, el 2 de octubre del mismo año. Auxilio, que por entonces vivía en el DF ganándose la vida en trabajos esporádicos y frecuentando de noche la bohemia capitalina azteca, se hallaba en el baño de la Facultad de Filosofía y Letras en el momento en que los militares invaden la Universidad. Ahí permanece varios días oculta. Este hecho (trágico, traumático) le da sin duda un cierto aire heroico con el que se le reconoce e ingresa a círculos de jóvenes poetas, en los bares y movida mexicanos. Haciéndose llamar "la madre de todos los mexicanos" o "la madre de la poesía mexicana" (Bolaño 11). Ella, distinta a Sara Sarandonga, es una intelectual, una poeta, pero ambas testigos y sobrevivientes de una generación, que es lo que aquí importa.
} 
CATEDRAL TOMADA: Revista de crítica literaria latinoamericana / Journal of Latin American Literary Criticism Espacios, discursos y modos de habitar Chimbote en Hombres de mar (de Óscar Colchado Lucio). Hacia una tradición de la poética de la frontera chimbotana.

como estas quien sabe porque lo ha vivido, complementado por quien no habiéndolo vivido aporta, no obstante, con su vitalidad (Chinchayán). Se tiene así los componentes imprescindibles para cambiar el mundo, los recursos que toda revolución necesita ${ }^{19}$.

Si la pesca y la vida nocturna son una ventana por donde ver parte de la realidad chimbotana, el Politécnico, colegio donde se forma la generación protagónica en el relato, complementa la mirada. Ambos espacios funcionan como gérmenes del movimiento que derivará en la histórica huelga de los pescadores. Si, como dijimos, la Flor de Chimbote como el colegio, representan espacios simbólicos en que, por un lado, a través de la bolichera, es posible conocer la vida de los pescadores que va y viene del mar a los burdeles y viceversa, por otro, por el Politécnico, se conoce el mundo escolar, el de la juventud chimbotana, con sus sueños e ímpetu irrefrenable de cambio. Mientras una realidad se presenta en plena faena pesquera, la otra lo hace desde la sala de clases, en repercusión siempre con la comunidad que es el barrio. Por el colegio se ingresa a ese universo de la vida cotidiana donde se congrega la familia con el espacio barrial. Los muchachos son puente entre ambos mundos, al modo como los pescadores lo son entre la pesca y el prostibulo. Y cada uno aporta lo suyo: los viejos pescadores la experiencia, los estudiantes la fuerza. Competencias que a lo largo de la novela se refuerzan y avanzan hacia una misma dirección para fundirse y confundirse en el encuentro que se da en el lugar público que es la plaza, el ágora, y que viene a ser el tercer espacio simbólico que vamos a abordar al final de este estudio.

Todos los elementos que acuden a la configuración de este espacio cuyo epicentro es el aula del colegio técnico, como una realidad que repercute y se refleja en los estratos familiares y comunitarios de barrio, formando una unidad social y cultural representada por el universo juvenil, pertenecen a un imaginario común que variadas expresiones estético-culturales plasmaron, pero ninguna

${ }^{19} \mathrm{Me}$ entero en el último viaje que hice a Chimbote que Sara Sarandonga sigue viviendo en el puerto, y que su historia es más o menos como la cuenta Colchado. 
como la música popular. Va a crear ésta un estilo musical propio que quedó arraigado en el inconsciente de la población adolescente de la América Latina de los años setenta. Me refiero a lo que etnomusicólogos y estudiosos de la cultura de masas, como Jesús Martín-Barbero, ha denominado, en base a una matriz de sensibilidad común ("sensibilidad primordial"), conectada a lazos familiares: "integración sentimental latinoamericana". Se trata de una expresión melodramática que estaría revelando una estandarización de maneras de sentir y expresar las emociones por medio de gestos, sonidos, ritmos y cadencias literarias comunes. Todas estas prácticas del sentir se canalizan a través de la llamada "balada romántica latinoamericana" o simplemente "balada latina", un registro musical que hasta hoy se da pero que tuvo su máxima vigencia entre la década de 1970 y mediados de los ochenta. Un género musical originario de la copla española pero que en territorio latinoamericano se va a transformar en un fenómeno popular y masivo, y altamente comercial que por medio de la televisión — en formato telenovela - llegará a todos los estratos de la sociedad, poniendo lo íntimo y subjetivo en el espacio público. De contenido cercano y directo, en un lenguaje ni sutil ni metafórico, antes natural y espontáneo, la balada calará hondo en los jóvenes de sectores populares que verán en ella un modo de autoidentificación que el tango, la ranchera y sobre todo el bolero (con los cuales guarda una estrecha relación, en particular con este último) no eran o no estaban, por el lenguaje elaborado y el alto contenido simbólico que portan, así como por su sutileza y sofisticación, etc., siendo capaces de dar cuenta de ese nuevo complejo escenario urbano moderno y popular que se estaba viviendo ${ }^{20}$.

\footnotetext{
20 Pongamos dos clásicos, un bolero y una balada, que por sí solos explican esta diferencia. Leemos en "La barca": "Dicen que la distancia es el olvido, pero yo no consigo esa razón, porque yo seguiré siendo el cautivo, de los caprichos de tu corazón... Hoy mi playa se viste de amargura, porque tu barca tiene que partir a cruzar otros mares de locura, cuida que no naufrague tu vivir...". Y ahora en "Fuiste mía un verano": "Hoy la vi, fue casualidad, yo estaba en el bar, me miró al pasar, yo le sonreí y le quise hablar, me pidió que no, que otra vez será... Fuiste mía un verano, solamente un verano, yo no olvido la playa, ni aquel viejo café, ni aquel pájaro herido que entibiaste en tus manos...". Es evidente en el primero su contenido metafórico, irreal, de un lirismo más elaborado que contrasta con la inmediatez y materialidad del bolero de Leonardo Favio. Mientras el bolero es un poema, la balada es una crónica. Una historia sencilla, común, sacada del cotidiano barrial.
} 
En un contexto más amplio, este fenómeno social que la balada latina recrea, configura un tipo de sujeto que de una $\mathrm{u}$ otra manera, deliberada $\mathrm{o}$ desintencionadamente, en forma expresa o quizá más aludida, está presente en la obra del autor de Rosa Cuchillo y Del mar a la ciudad. Es cierto que los personajes protagónicos que entonces son estudiantes aún se hallan en ese limbo de la primera juventud y que, por lo tanto, no existe en ellos todavía esa libertad propia del adulto que le brinda el hecho de trabajar. Siendo aún estudiantes no gozan de la autonomía que da el dinero para acceder al mundo. Y esto, sin duda, es un factor que juega acá un rol positivo ya que permite situar a estos jóvenes en un constante esfuerzo emancipatorio. Una lucha que se da siempre entre un Yo contra distintos frentes: la familia, el colegio, los pares y por extensión el sistema, el régimen de poder imperante. La figura es la de un joven (las canciones en su gran mayoría giran en torno a un discurso varonil: el galán es un muchacho que pretende a una encantadora chica) ${ }^{21}$ con trazas de trotamundos; un soñador, un calavera que desde su sesgo romántico e idealista promueve un aire de irreverencia casi inocuo. Frecuenta bares, cines, cafés, pista de bailes; fuma marihuana y tiene sexo ocasional. Prácticas del contexto típicamente urbano en el que se intenta construir. Y para eso se apropia de la calle, espacio del amor y de la resistencia. Hace de ella una trinchera en cuyo empoderamiento rechaza todo cuanto no se avenga a ese modelo de hombre nuevo que busca reconocimiento. Ve con recelo, por eso, su pasado como sus raíces rurales (es el último eslabón de la migración campo-ciudad). Está en ese proceso de acomodo, en una débil señal

\footnotetext{
${ }^{21}$ Sin duda hay aquí una deuda de género pendiente. Es verdad que la mayoría de intérpretes de la balada latina son hombres y que sus letras reproducen esa lógica galantería tan típica del romanticismo español, en que la figura de mujer queda relegada a objeto de deseo, casi sin decisión ante los caprichos del joven conquistador. ("Adiós chico de mi barrio", 1970, de una argentina, que también compuso "Muchacho del blue jeans", es una excepción a la regla). Colchado reproduce este mismo modelo. El caso de Lily, como botín en la pelea entre Pocho y el Gordo Grados, es el más claro ejemplo de un machismo gravitante y que bien podría ser materia para la crítica. Se puede aducir que los muchachos son estudiantes del Politécnico, colegio de varones, y que son ellos los que salen a la búsqueda de las muchachas. Otra verdad. Pero eso no quita la falta de la siempre interesante y compleja mirada de una mujer joven. De Mara Salinas es la única que apenas, y si es que, se ofrece una imagen más plena o menos superficial del personaje femenino. La única en el fondo que brilla con luz propia es Sara Sarandonga, pero esta ya pertenece a otro contexto, distinto al que nos estamos refiriendo en este apartado.
} 
de pertenencia. El barrio será su primer y en muchos casos único peldaño de ascenso. Este sujeto instala así una cosmovisión a partir de ese idealismo que se muestra disconforme con el trabajo asalariado, la sobreexplotación y en general con la desigualdad y la pobreza que son parte de su cotidianeidad. De ahí pues su incomprensión e inacabamiento. Al carecer de referentes, se arma en esa falta (familia, trabajo, estudios, expectativas), en esa realidad incierta e inestable. Lo que lo lleva a una búsqueda de no se sabe qué porque al no saber quién es imposible saber qué quiere. Todo, avanzada la década, lo conduce a la disyuntiva ineludible entre la militancia o la resignada aceptación del esclavo del sistema que inauguran los años ochenta 22 .

En este ambiente queremos situar al grupo que Colchado ofrece en su novela. Es cierto que el panorama sociocultural que acabamos de reseñar no está así de presente en Hombres de mar, y entonces, podemos pensar, en Chimbote, pero creemos que en un compromiso crítico serio y responsable caben todas las posibilidades que permitan configurar en su totalidad el referente histórico que la obra aborda. Los personajes siguen siendo los que Colchado imaginó y plasmó, nosotros lo que hacemos es ampliar el escenario en que se mueven a fin de verles en la complejidad que como sujetos históricos tienen. Aquí más que individuos vemos un colectivo, una generación que encarnó estos ideales y que por lo tanto sufrió las consecuencias de la decepción. Fueron ellos las principales víctimas de una sociedad que vivió en carne propia las últimas dos décadas de la Guerra Fría y el panorama que en el contexto global ofrecía la escalada del capitalismo mundial que en su postura anticomunista propagó las dictaduras militares en gran

${ }^{22}$ En esta decisión vital es cuando la balada sufre un quiebre o inflexión determinante. Una parte de la creación asumirá el compromiso con la llamada "canción protesta", ligada a las reivindicaciones de izquierda, en que sus máximos exponentes sufrirán persecuciones y exilios (Piero y Leonardo Favio). Mientras que la otra será seducida por el entonces incipiente pero prometedor mercado mundial de la música. Una empresa discográfica altamente desarrollada que busca atraer a un público cada vez mayor por medio de contenidos acríticos que desconflictúan el contexto y que buscan borrar las diferencias. Las canciones apuntan hacia una homogeneización del referente como estrategia comercial que les permita masificar el producto, y que lo hará en la medida que logre vuelo internacional, alcanzando un éxito que se medirá en su ingreso o no al mercado estadounidense, al escenario miamiesco (Armando Manzanero, José Feliciano, José Luis Rodríguez, Roberto Carlos, y los españoles Julio Iglesias y Camilo Sesto, etc.). 
CATEDRAL TOMADA: Revista de crítica literaria latinoamericana / Journal of Latin American Literary Criticism Espacios, discursos y modos de habitar Chimbote en Hombres de mar (de Óscar Colchado Lucio). Hacia una tradición de la poética de la frontera chimbotana.

parte de la región. No obstante la pluralidad del personaje, Rojitas y de algún modo Mara, Mariela Salinas, su enamorada, por sus rasgos propios, son las figuras que más y mejor hablarán por el conjunto ${ }^{23}$.

En efecto, Rojitas, narrador-testigo y que a ratos funciona como la voz de una consciencia particular que evoca desde el presente sus años de juventud y que, acudiendo a la estrategia paraliteraria que elige Colchado, sería Manuel Rojas Padilla, el joven senderista caído en combate, es, como todos los personajes de la novela, una figura de la cual no se puede obtener una imagen en plenitud, no posee los elementos suficientes que le den un protagonismo central y en consecuencia no adquiere en la obra vida propia, el perfil individual y autónomo que brille por sí mismo. Pero esa falta de complejidad e incumplida entereza como sujeto pleno, no impide ver en Rojitas, por su carácter sugerente y por su marcada presencia a lo largo del relato, al resto. A esto hay que agregarle su condición histórica como personaje que tiene su contraparte en la realidad. No sólo habla Rojitas sino también Rojas Padilla por medio de su cadáver que porta y aporta el manuscrito-testimonio de una historia que precisa contarse. Esto le da a la novela un aspecto singular $\mathrm{y}$ un espesor significativo que tensionan $\mathrm{y}$ problematizan la siempre compleja relación entre realidad y ficción, producida en este caso del entrecruzamiento entre mito, historia y literatura.

La presencia de Rojitas se retrotrae al momento inicial en que conoce a Mara, suceso que es ya en sí mismo una balada: yendo al colegio en bicicleta de pronto se cruza con una "preciosa y esbelta muchacha en buzo que venía corriendo en sentido contrario, como a dar [le] el encuentro" (Colchado 209). La vida amorosa de esta pareja la verdad que no tiene mayor trascendencia, transita más en la ensoñación, en evocaciones individuales, que no pasan de miradas y

\footnotetext{
${ }^{23}$ El grupo queda reunido en Los Tiburones, la gallada, la pandilla del barrio, compuesto, con más o menos participación, por: Rojitas, Mara, el Botas, Lily, Naras (Rubén Malca), Patricia Bochkoltz (la gringuita de La Caleta), Gordo Grados y Negro Matos. Por fuera, el adulete y soplón Galladaza y el Pocho (el pituco, ex novio de Lily quien lo deja por el Gordo Grados). También gravitan aparte, ligados a la acción política: Dany Barrios (lector de Qué hacer, de Lenin) y, claro: Pedro Chinchayán.
} 
deseos mutuos, a un par de encuentros concretos, en uno de los cuales tiene aparición el elemento mítico (cuando El Viejo Tijera se les presenta en forma de pelícano). Lo verdaderamente importante, para nosotros, sin restarle por cierto valor al componente mágico-religioso, está en ver cómo se construye el personaje Rojitas en ese proceso vital cuyo cuerpo termina baleado en las calles de Lima, casi dos décadas después. La clave la entregan los, para usar un término reusado en estas materias, lugares comunes de los, todavía más reusados, ritos de iniciación.

Después de ese cruce con Mara, Rojitas acude al Bar de Pedrito. Ahí estaban el Botas y Aníbal Grados Beltrán, bebiendo cerveza. Rojitas se les suma, pero con esa distancia y timidez del inexperto ${ }^{24}$, lo que queda demostrado en actos (no sabe servir la cerveza ni conoce las lógicas propias del beber con amigos), como en cuestionamientos que lo acechan interiormente. Ellos ya han tenido novia, y se han iniciado sexualmente. Cuentan sus logros, se ríen, disfrutan de sus aventuras ante un Rojitas que no tiene mucho que aportar. "En el baño te preguntaste si es pertinente contarles tu amor por Mariela [...] Mas luego caíste en cuenta de que, acaso, tu amor platónico por ella se vería ridículo frente a las experiencias eróticas, carnales, que ellos acababan de contar" (Colchado 215). Rojitas si bien con esto demuestra su inmadurez frente al resto también revela su anhelo de iniciación y de ingreso definitivo a Los Tiburones, paso que queda zanjado en dos hechos: la primera borrachera y su primer coito. "iSalú, compadres!, [dice Gordo Grados]: Por el Poli, Los Tiburones de mi barrio y las hembrichis" (Ibid). Dando así por inaugurada la primera parte del ingreso de

${ }^{24}$ Hay un dato importante sobre la personalidad de Rojitas. Cuando los profesores del colegio descubren que él es parte de los "revoltosos", uno de ellos, sorprendido, dice: "¿Rojas? [...] i,Yél por qué si es tan tranquilo y estudioso?". Asocian los profesores la actividad política a un tipo de personalidad inestable, desordenada y problemática. No les sorprende por eso que Gordo Grados esté metido el política, porque es un alumno "sobre quien había ya muchas quejas anteriores de su pésimo comportamiento" (Colchado 388), pero sí la presencia de Rojas Padilla. En Chile, para las movilizaciones estudiantiles del 2011, famosas fueron las declaraciones de un político y empresario de derecha cuando señaló, ante el fenómeno que estaba sucediendo a nivel nacional, que No nos va a doblar la mano una manga de inútiles subversivos. Esto obviamente responde a la mirada histórica cómo la oligarquía entiende los movimientos sociales: con prejuicios de todo tipo. 
CATEDRAL TOMADA: Revista de crítica literaria latinoamericana / Journal of Latin American Literary Criticism Espacios, discursos y modos de habitar Chimbote en Hombres de mar (de Óscar Colchado Lucio). Hacia una tradición de la poética de la frontera chimbotana.

Rojitas al grupo y por tanto a su plena juventud. La otra se dará en el prostibulo Tres Cabezas. Aquí se desvirga.

Tenías miedo y un terrible cargo de conciencia. Pensabas en tu madre y en Mariela. ¿Serías digno de ella luego de lo que ibas a hacer? Por otro lado sentías fuertes deseos de mujer, ya eras un hombre y casi la mayoría de tus compañeros experimentaba con putas [...] Quizá era urgente esa experiencia para ser más aventado, más entrador con las mujeres, como el Naras, por ejemplo, pensaste (Colchado 218).

Y así, con una "zamba enorme, bien despachada", logra Rojitas no sin las dificultades de rigor, cerrar su proceso iniciático. 'Poco después, sobre los pechos aún firmes de la monumental morena, sentiste que se diluía tu adolescencia" (Id. 220). Acá, con sus amigos mayores, en el bar y luego en el prostíbulo; con la primera borrachera y la primera experiencia sexual, se pone a prueba para Rojitas un pacto de amistad basado en la lealtad y en el arrojo de atreverse a dar el salto del niño al hombre. Claro, Rojitas no sólo se atreve sino que pese al conflicto interno propio entra en ese juego de rupturas. Por eso que las imágenes de la madre y de Mariela están siempre presentes. Porque su madre le había hecho un mandado (tenía que ir a pagar un préstamo, plata que se gasta en cervezas), y porque sentía la ilusión de un compromiso hacia Mariela. Sin embargo cuando decide, en el conflicto, y pese a las consecuencias, seguir adelante, es que pasa de un estadio a otro, rompe la barrera que lo convierte en personaje medido en su calidad de tiburón.

Por otra parte Mariela, Mara, de 16 años, parece vivir su propio encanto, su amar en silencio. No son en realidad pareja, no viven la relación; la desean, la anhelan, la imaginan. Se corresponden sólo en un plano imaginario. Mara, en el mar, "su mirada tiende a encontrar otra vez los ojos de ese muchacho delgado, de cabellos ligeramente ondulados, a quien ve pasar de cuando en cuando en 
bicicleta, pero que nunca se detiene aun cuando pase muy despacio, rozándole la falda" (Colchado 224). Esto revela algo más. Expresa ciertamente ese tipo de relaciones de esta generación que parece vivir en un mundo más iluso que real. La falta de compromiso, la evasión, ese pasar sin detenerse, son todas características de personajes en formación que aún no han logrado configurase en sujetos plenos. (Seguramente el único con este rango es Rojas Padilla). Mariela escribe poemas que nadie lee, que a Rojitas no llegan. Pero la significación de Mariela rebasa este hecho puntual. $\mathrm{Su}$ presencia en la novela está directamente relacionada con el mundo mítico-religioso que la obra, como dijimos, recoge, como una realidad ineludible dentro del contexto totalizador de Chimbote. Apela por lo tanto a un insobornable compromiso ideológico. No vamos a ahondar aquí en el paralelismo entre estos espacios y temporalidades que afectan los universos narrativos de la obra. Seguiremos la línea que hemos trazado por el lado propiamente literario del relato, en el que Mara es más la pretendida de Rojitas que de Mellizo Marino, más Mariela Salinas que Yéncala, y en el que ella, su pretendiente y amigos de barrio y escuela, irán siendo parte del proceso social que culminará en la ya citada huelga.

Al modo de cuento tradicional, la novela funciona a partir de una estructura narrativa en cuyo inicio se van presentando o exponiendo hechos y personajes que en el transcurso del relato y en la medida que comienzan a interactuar recíprocamente, hacen de ella una historia compleja, un entramado en que las múltiples realidades conforman el conjunto de la obra narrativa. Una historia hecha de mundos que en sus acercamientos se atraen y se repelen, creando finalmente un universo en el que operan dos fuerzas de poder: una centrípeta que es la que le pertenece a la hegemonía central, encarnada, digamos, por la dictadura militar — desde Velasco Alvarado a Morales Bermúdez- y los intereses de la empresa pesquera, y que en conjunto promueven elementos reaccionarios y represivos; y otra centrífuga, que a partir de impulsos principalmente generados por las fuerzas de base sindical (pesca y siderúrgica) y estudiantil (colegios encabezados por el Politécnico), como también por los 
modos de relacionamiento dentro del cotidiano, descentran ese poder de la elite desacatando o subvirtiendo esas lógicas represoras. Estos son los dos frentes visibles de la pesca: una actividad altamente lucrativa de un lado, que va en contra de los propios trabajadores ${ }^{25}$, y un fenómeno cultural, de otro, que envuelve la vida toda del pescador. Pero, como digo, son la cara visible. Por debajo, entre medio de cada instancia va surgiendo un tejido de contrariedades propias de una sociedad en crisis y que en el fondo es a lo que Hombres de mar le dedica sus más de quinientas páginas. Las posturas personales y colectivas que manifiestan los habitantes del puerto contra la hegemonía y lo que hacen o dejan de hacer para revertir esa sujeción en el que se juega el sentido último del habitar la ciudadpuerto es, al final de cuentas, la clave, según nosotros, para entender la obra.

De ahí que interese terminar este ensayo abordando el cronotopo que es la Plaza de Armas, pero no como instancia terminal, como punto de llegada, sino más bien como punto de partida de la novela; que equivale a decir, en un plano contextual histórico, como el inicio de un nuevo ciclo vital de la ciudad-puerto y cuyo resultado bien puede verse a partir de la urbanización y desplazamiento de Nuevo Chimbote. El Chimbote nuevo que gravita ahora en torno a su Playa Mayor. Para eso volvamos sobre las ideas que en el marco teórico hemos señalado sobre el valor que tiene la polis y particularmente la figura del ágora para el mundo urbano occidental. El ágora, la plaza pública, es eminentemente el espacio para el intercambio de ideas. Su valor por tanto radica en cuanto espacio inmaterial, moral, simbólico. Es un espacio vacío que está ahí — libre, abierto-

25 En una reunión que se realiza en el Politécnico para evaluar la situación, queda demostrada la ignorancia como la obvia preocupación de los padres de los estudiantes, sobre lo que sucede. En general reina un desconocimiento debido a la tendenciosa propaganda que promueve el oficialismo, que parte de los mismos profesores, quienes bajo el estigma de revuelta, desorden, violencia, o simplemente excusa injustificada para no asistir a clases, banalizan o cuando no criminalizan el movimiento social. En este ocasión, Dany Barrios, ante la pregunta de una madre de por qué hacen eso, responde: Por "las injusticias y los abusos que se comenten contra el pueblo y con nosotros los estudiantes, señora”. “QQué abusos?”, pregunta un padre. “Cómo no sabe usted, señor? Por ejemplo, los abusos que comete el gobierno militar contra los pescadores queriendo arrojarlos abusivamente de sus puestos de trabajo". Este es el "problema principal", remata Barrios (Colchado 410-411). Claro, y esto revela el grado de consciencia que ya existe en los estudiantes y cómo los padres al enterarse comienzan, de a poco, a tomar partido por la causa. 
dispuesto para ser llenado por el foro público, en la asamblea informal, que crean los ciudadanos y con el cual construyen su habitar. En la medida que se intercambian ideas y se generan interpretaciones sobre ese buen vivir-que es el fin último del habitar - se avanza a ese habitar feliz, en poeta, que proponían los sabios. Sin este encuentro/desencuentro sobre el espacio público que físicamente es la plaza, no hay discusión sobre el bien común y por tanto hay imposición, desacuerdo; un no-habitar. Entonces, siguiendo este razonamiento, la ciudad clásica al ser esencialmente política se vuelve sinónimo obligado de polis. Ahí se hace visible la cuestión pública, la politeia que es una suerte de acuerdo común de cómo vivir mejor. Cómo vivimos, cómo habitamos este espacio es tema del foro público y de quienes a la plaza concurren. Por lo mismo, dijimos en la parte teórica, ágora es reunión y palabra más que lugar construido. El locus de la elocuencia, antes que monumento central, que exige la deliberación y la inteligencia común, es decir: la confrontación en base a la disputa, a la polémica, al altercatio. Es el ágora por tanto el punto de encuentro neutral que se llena en la palabra y en la conversación, o sea: en el diálogo de todos con todos. Sin eso no habría habitar, y sin habitar no hay ciudad, porque hay ciudad en la medida que se habita y no se habita de otra forma que no sea en poeta, felizmente.

Siendo así, entonces, cuando se discute sobre ese buen vivir lo que se expone es el juego de fuerzas antagónicas que rigen los intereses de los ciudadanos. En Hombres de mar, expresamos arriba, se da, en efecto, eso: la confrontación de ideas-fuerzas disímiles respeto a ese habitar que estaría regido supremamente por la pesca, más abarcadoramente: por el mar. Simbólicamente lo que se debate es que si se habita con o si se habita contra el mar, y en la que una u otra opción definirá en resumen si hay o no hay un habitar porteño. En una palabra: se discute el valor del mar como medio de explotación y beneficio comercial o como fuente dador de vida y generador de habitar. Así, como para unos la mar es un medio explotable y cuya relación con él no es sino de uso, como un recurso natural más que está ahí para ser aprovechado, para generar riqueza (que es también modernización, trabajo, civilización, crecimiento urbano), 
para otros en cambio la mar es sobrevivencia, donde el sustento básico es sólo parte de una relación mucho más entrañable que involucra el ser y la identidad del habitante. Digámoslo de otro modo: la discusión está en qué posición ocupa Chimbote respecto al mar. ¿Es la ciudad que se industrializa gracias a la utilidad que hace de la pesca o, por el contrario, es la ciudad que se va a construir en su relación con ese medio natural? Si es lo primero, la ciudad está antes y por sobre el mar, de modo que el puerto depende de la industria; si, en cambio, es lo segundo, la ciudad no existe si no es por el mar, y entonces habría una (inter) dependencia ligada a un gran tiempo en que la artesanía como la industria son parte de su historia. ¿Cuál de los dos Chimbote interesa más: el industrializado o el del antiguo pueblo de pescadores artesanales? Sin duda que ambos.

En esta lógica se mueven los intereses del universo chimbotano; y estos son al cabo los que llegarán a tomar posiciones enfrentadas en ese espacio que aún no se llena y que será llenado al final de la novela, ahí donde todo comienza: en la Plaza de Armas, en el diálogo, que puede incluso derivar en violencia ${ }^{26}$. Y que, como todo, no es más que una cuestión de equilibrio, de la búsqueda de una esquiva armonía de las partes. Porque no se trata ni de condenar la industria pesquera como medio legítimo de desarrollo urbano $-\mathrm{y}$ sin la cual Chimbote no habría llegado a ser lo que es ni nosotros a dedicarle estas reflexiones-, ni menos de obnubilar, pasar por alto la historia de un antiguo pueblo de pescadores artesanales de quienes se heredó una manera de habitar sus costas. Se trata, por lo tanto, de un modo de hacer que exige buscar puntos de convergencias que ayuden a entender que ese encuentro de mundos no sólo es inevitable sino que en esa inevitabilidad se vuelve, paradojalmente, hacia nosotros, como el desafío ante

\footnotetext{
26 Resulta pertinente acá "Carta a Daniel Havély", de George Sorel. El pensador francés en esta carta legitima, a partir del mito, el derecho a la huelga general. "[L]os hombres que participan en los grandes movimientos sociales imaginan su más inmediata actuación bajo la forma de imágenes de batallas que aseguran el triunfo de su causa. Yo propuse denominar mythes (mitos) a esas concepciones cuyo conocimiento es de tanta importancia para el historiador. La hue lga general de los sindicalistas y la revolución catastrófica de Marx, son mitos". Para Sorel, la huelga revolucionaria es un mito social ya que el mito se reactiva en ella, y por lo tanto, al poseer ésta este componente transhistórico, adquiere un legítimo valor como defensa contra la opresión burguesa (Sorel 11-15).
} 
nuestra propia modernidad regional. Hombres de mar al hacer presente el conflicto funciona, así, no como retrato reflejo ni como recetario al problema; funciona ante todo como un bien estético que lo ilumina -que muestra sus fisuras para dejarlas ahí: sugerentes, abiertas - con el propósito de ser sometidas a múltiples interpretaciones. Nombra e instala el conflicto en la plaza misma, como un espacio también vacío que nos impele a debatir, a tomar partido y a discutir reflexivamente sobre un hecho que va más allá de lo que la novela misma nos presenta. La obra de Colchado nos convierte pues, en este sentido, en lectores-habitantes de un espacio que nos afecta en tanto sujetos históricos latinoamericanos. Nos compromete, dentro del gran foro público, a tomar la palabra y a pronunciarnos desde una crítica racional respecto a ese modo de hacer que implica la cuestión sobre el poder y el habitar nuestras ciudades, en especial nuestras ciudades-puertos del litoral subpanameño, pero en rigor el desafío es a reflexionar sobre nuestra América, espacio geocultural en relación siempre compleja con Occidente.

Digamos que a lo que nos lleva esta novela es a cuestionar la realidad como a proponer posibles salidas. Pero por el modo como es tratado el asunto no se trata sólo de un problema lógico racional, de un recurso ubicado sólo en el plano de la razón, en el pensamiento puro y abstracto, a lo que suele reducirse comúnmente la política tradicional. Al tratarse aquí de un fenómeno cultural afecta al hombre y por tanto al racionamiento como también a las experiencias sensitivas, a las emociones, es decir a la parte irracional, llámese mítica, mágica, maravillosa del hombre chimbotano, y que en la obra quedan, como hemos visto, claramente expuestas. Convergen, así, reducidos: una razón crítica y un saber mítico. Uno proveniente del pensamiento kanteano occidental, otro, depositario de la milenaria tradición indígena. De modo que la plaza entonces va a reunir, en la figura política de la huelga, estas dos tendencias que van a participar en la confrontación de fuerzas centrípetas y centrífugas. Si bien es plausible aseverar que la lógica del dominio que impulsa el sistema represivo y que respalda el capital pesquero es la racionalidad instrumental que pone la razón al servicio de 
sus propios intereses, y que, por el contrario, los impulsos de la comunidad chimbotana generados de las distintas bases sociales son el resultado de energías irracionales, esto es y no es, o sea es pero en forma relativa. No podemos, creo yo, separar o distinguir así, taxativamente, estos universos. $\mathrm{Y}$ esto porque las estrategias hegemónicas tienen su ración importante de irracionalidad (¡Qué muestra más clara que las últimas dictaduras! ¡Qué más bárbaro e irracional que la Dirección de Inteligencia Nacional, la DINA en el Chile de Pinochet!) ${ }^{27}$, como porque, es obvio, las tácticas ${ }^{28}$, que propugnan la revolución y la resistencia, no son pura pasión desenfrenada (ya hemos visto la estricta racionalidad con que opera el marxismo sindical. Dany Barrios y Pedro Chinchayán no son sino la mejor muestra —y de ahí la importancia del acto sexual de Chinchayán, donde la quiebra-). No hay aquí, porque no tienen valor, criterios cerrados o verdades

27 Ya en el Facundo, de Sarmiento, se plantea el problema sobre esa irracionalidad de la barbarie la que, estaría representada por Juan Manuel de Rosas. La barbarie no es, en este sentido, exclusividad del gaucho, de los indígenas o de los más pobres, sino del militaris mo autoritario, de los totalitarismos y de las dictaduras de todo orden. Otro ejemplo es el de Martí, en "Nuestra América", donde si pensamos sobre el origen del caos, este no viene de la "barbarie", es decir: de la ausencia de modernidad, de la no-civilización: "[L]os hombres naturales han vencido a los letrados artificiales. El mestizo autóctono ha vencido al criollo exótico. No hay batalla entre la civilización y la barbarie, sino entre la falsa erudición y la naturaleza" (Martí 482. Ver también Ramos, Desencuentros 287 y ss). Por último, no deja de sorprender la postura que asume Vargas Llosa en el informe sobre la masacre de Uchuraccay. Recordemos que el peruano preside la Comisión de la Verdad que investiga este atentado en el que un grupo de periodistas son asesinados por comuneros indígenas quienes, aparentemente, habrían confundido a los reporteros con senderistas, y que, en acto de venganza (porque Sendero habría matado a parte de su comunidad), masacran violentamente. No deja de sorprender, digo, que en el resultado del informe, el Nobel se ubique, dice Moraña, siguiendo en esto un artículo de Jean Franco: "en el lugar de la racionalidad y sentido común en relación a un mundo [el de los comuneros de Uchuraccay] que presenta como un espacio anacrónico y caótico, marcado por la violencia y las tendencias mágico-religiosas que contrastarían por su irracionalidad con los modelos dominantes de la nación criolla" (Moraña 30-31). O sea, vemos en el escritor peruano otra vez la suma en que los bárbaros son los indígenas y que, la nación blanca criolla, la que él muy bien representa, los civilizados. Vuelve con él la histórica dicotomía sarmientana a punto cero.

28 Michel de Certeau propone para este caso la diferencia entre estrategia y táctica. Dice el francés, en el contexto de las formas de hacer de las culturas subalternas, que la estrategia le pertenece al sistema opres or en tanto la táctica al reprimido, pero que a través de este medio logra subvertir. En lo que llama "el arte del débil", distingue como recurso la táctica: método o argucia furtiva y azarosa pero potencialmente sediciosa inserta en una sociedad mecanizada que vigila y castiga. Porque una sociedad que privilegia el aparato productor va a contar siempre -dice él-con elementos que jugarán en su contra, que no se reducen a ella (De Certeau 26). 
absolutas, ya que de lo que se trata es de mirar por el ojo del inacabamiento y la perfectibilidad propios de la raza humana.

Acá, en el ágora, tendrá lugar pues el desenlace de una historia que apenas comienza a inscribirse en las páginas de la crónica social y política peruana de los últimos años. Si la plaza pública es el espacio de la disputa, la huelga es el motivo que lleva a hacer de este sitio el epicentro de la novela. Eso quiere decir que en Hombres de mar la bolichera así como el colegio técnico y todos los espacios sociales que cada uno involucra, no sirven más que agentes propiciadores hacia el hecho central, la historia en proceso que revelará las condiciones actuales de la sociedad peruana y por extensión latinoamericana. De modo que la huelga, los paros y hasta la Marcha de los Cuatro Suyos (2000) ${ }^{29}$ operan en la novela, en el discurso ficcional, más como hitos referenciales de carácter alegórico que como sucesos de la realidad misma. Todos estos acontecimientos que tienen su contraparte en el mundo real, adquieren aquí un valor simbólico que no sólo trasciende la realidad sino que, como señala Bachelard, la afecta (Bachelard 12). Un acto creativo que al tomar el referente y situarlo en el plano de la imaginación, renueva la experiencia, es decir que al trastocar desde ese gesto estético la realidad, le está ubicando en el lugar del símbolo; en esa revisión le da a la experiencia sentido poético ${ }^{30}$, y por tanto favorece al propósito nuestro de configurar la poética de la frontera. Hace de esa realidad común y corriente un hecho heroico, un acto nada menos que épico. La eleva a una dimensión universal donde es posible verla $\mathrm{y}$, a través del democrático ejercicio de la interpretación, lograr comprender nuestro mundo inmediato, nuestra propia cotidianeidad. Con

\footnotetext{
29 Movilización nacional que además de pretender sacar a Fujimori a la fuerza, denunciando el fraude electoral, y con ello dejar a Alejandro Toledo en el poder, tiene una significancia integradora y simbólica a la vez que apela estratégicamente a la antigua organización estructural en que se dividía el Tahuantinsuyo, el imperio inca. Aunque tuvo su principal escenario en Lima, repercutió en todo el país; todas las regiones se congregaron en el epicentro limeño.

30 "Digo poema para toda a literatura, não somente no sentido restrito habitualmente para a 'poesia' por oposição ao 'romance', abafando-o sem mesmo tomar conhecimento da ausência de distinção entre a poesia e o verso, com a redução da poesia a um gênero. No que concerne à relação entre o poema, um pensamento do poema e esta atividade particular da linguagem que consiste em renovar a experiência" (Meschonnic, XVIII).
} 
CATEDRAL TOMADA: Revista de crítica literaria latinoamericana / Journal of Latin American Literary Criticism Espacios, discursos y modos de habitar Chimbote en Hombres de mar (de Óscar Colchado Lucio). Hacia una tradición de la poética de la frontera chimbotana.

El zorro de arriba y el zorro de abajo, con Hombres de mar y con muchísimas otras expresiones artísticas ${ }^{31}$, Chimbote no es el mismo, o es el mismo y otro a la vez. Sin duda todo lo que se ha pensado y dicho sobre el puerto le ha afectado como realidad, ha hecho crecer en él un carácter, un potencial como espacio del habitar.

Con este convencimiento queremos abordar el tercer y último espacio que corresponde al ágora, ahí donde se juntas los otros dos espacios que vienen avanzando hacia este lugar estratégico de la ciudad. Reúne el ágora estas otras experiencias del cotidiano, donde van a exponer el resultado de un proceso particular para aunarlo en un reclamo general que viene a ser, dijimos, el grito de protesta por un modo de habitar el espacio porteño. El ágora escenifica y canaliza esa fuerza en una voz polifónica que será la que la novela viene modulando y que al final trascenderá a nosotros como lectores. El grito cobrará real sentido cuando se proclama en la Plaza de Armas y cuando es la expresión de un discurso político previamente elaborado. Un pregón que sólo se da en el ágora y como manifestación de un sentir colectivo histórico: un deseo o una necesidad que comienza afirmándose: “¡Y va a caer! ¡Y va a caer! ¡La dictadura va a caer!" (Colchado 378). En el ágora la exclamación es sentencia cuando es coral y cuando quienes la cantan son agrupaciones (la $\mathrm{FECH}$, los sindicatos, los estudiantes de los colegios) que representan la población en su totalidad. Esa voz colectiva que viene de una inquietud personal, que luego se sociabiliza en una asamblea y que después se transforma en bandera de lucha de un grupo organizado, en el cronotopo del ágora, se legitima, adquiere fuerza y valor.

\footnotetext{
31 Si pensamos sólo en la literatura, el trabajo que ha realizado Río Santa Editores, que publica y promueve títulos en todos los géneros, recreando y construyendo la identidad de Chimbote. Otros textos de Colchado, como Del mar a la ciudad, y el Grupo Literario Isla Blanca, que él mismo funda, así como la producción que viene del poeta Juan Ojeda (1944-1974), hasta narradores recientes, como Braulio Muñoz (1946), autor de la galardonada Alejandro y los pescadores de Tancay (2004) y el también celebrado Fernando Cueto (1964), con novelas y poemas que evocan el Chimbote de la memoria, en especial el del pasado prostibulario, con la novela El diluvio de Rosaura Albina (2014) y otras. La creación, más la crítica, la difusión editorial y actividades de promoción lectora, etc., permiten hablar sin duda alguna de una activa y robustecida tradición literaria chimbotana, como la quisiera cualquier otra ciudad de la región.
} 
Bajo ese grito la plaza se pierde y resurge el ágora donde se va a debatir el, digámoslo así: ser chimbotano. Las cabezas visibles serán las de los mismos jóvenes que han venido construyendo ese discurso toda vez que a sí mismos. El proceso sin duda les involucra en su crecimiento como individuos, como personas individuales pero también como sujetos de una organización colectiva que se reúne para discutir ese bien común que es el habitar ese espacio social y por medio del cual resignifican su carácter de hombres de mar. Una discusión que, lo dijimos, no es siempre pacífica; la violencia es inherente a la huelga y a este tipo de manifestaciones en que se involucran rabias, frustraciones, deseos, de un lado, e intereses de poder político y económico, con dura represión policial, de otro. Como es el caso del velatorio de Plascencia, el pescador que es baleado por la espalda. Nada más simbólico para el caso que velar el muerto en el centro de esa ágora que está para el altercatio de, se supone, palabras, pero que puede derivar en violencia proveniente de las fuerzas ocultas del hombre en condiciones extremas. El derrame de sangre es parte de esa confrontación de ideas pero también de profundas y trascendentales pasiones humanas. El cuerpo del caído simboliza esa dualidad perdida-ganancia propia del mito. Una baja pero también un aliciente extremo que nutre, le da vida y sentido a la lucha. Sin muerte no hay vida. Pero para eso debe haber cuerpo y sangre, sin esos testimonios irrefutables de la muerte no hay sino desesperación y por lo tanto nula posibilidad de reconciliación. Con el cuerpo caído se cierra-abre una etapa; etapa que no puede nunca cerrarse con el desaparecido. He ahí una cuestión ética esencial para comprender el tema de la muerte, la memoria y la necesaria reconstrucción de toda la historia moderna y contemporánea de América Latina. Por eso la sangre del pescador muerto (y también de Gordo Grados) representa así no el fin sino el inicio de una lucha social que viene recién dándose. "Por la noche, los cadáveres fueron acomodados en la Plaza de Armas, lugar donde se hizo el velatorio". Ahí "yacía [el pescador] en ese barnizado cajón verde oscuro, por cuyo alrededor desfilaba casi toda la población obrera de Chimbote [...], quienes de rato en rato, 
CATEDRAL TOMADA: Revista de crítica literaria latinoamericana / Journal of Latin American Literary Criticism Espacios, discursos y modos de habitar Chimbote en Hombres de mar (de Óscar Colchado Lucio). Hacia una tradición de la poética de la frontera chimbotana.

a una sola voz gritaban, refiriéndose a ambos muertos: ¡Sus sangres derramadas/ jamás serán olvidadas?" (Colchado 497-499).

De lo anterior se deduce la tragedia del sacrificio y el valor que la muerte tiene en la lucha por las igualdades sociales. La novela como la historia, o esta historia novelada, no puede terminar sin el derramamiento de sangre. Omitir el hecho es negar nuestra propia historia atravesada por el sacrificio ante los intereses del mundo moderno. Somos parte de una realidad occidental en que la destrucción y el aniquilamiento son inherentes a nuestro proceso evolutivo. La espada y la cruz no eran únicamente símbolos: representaban el primer contacto real y directo con el mundo indígena. Y no sólo de parte de Occidente. zLos pueblos prelusohispánicos asumían también la muerte como elemento constitutivo de su cultura/identidad. Por consiguiente, el episodio de la muerte aquí no es gratuito, elemento decorativo: responde, como todos los mundos que la novela recoge, a una necesidad integradora que exige comprender nuestras sociedades en el sentido más abarcador posible. Los caídos de los años setenta en las luchas revolucionarias latinoamericanas reafirman todas estas aseveraciones. Desde el Che Guevara (1967) a Rojas Padilla (1989), la sangre derramada simboliza con fuerza todo el sacrificio que exige ni perdón ni olvido. Hacerlo sería traicionar el pasado y sellar para siempre la incapacidad de construir una sociedad más justa. Ya lo dicen los manifestantes en el ágora: la sangre jamás será olvida, y no sólo eso, sino que vengada, es decir, sentenciada, hecha justicia. La memoria es pues el único dispositivo que permite esa justicia y el camino para el reencuentro con nuestro tiempo. Hombres de mar, en ese sentido, refuerza, contra la amnesia del mundo moderno que cree siempre habitar un presente perpetuo en que todo comienza de nuevo, donde no hay pasado que entorpezca el proceso acelerado hacia delante, la búsqueda de la verdad que traslada la memoria. La obra de Colchado que estudiamos es un ejercicio de la memoria colectiva de nuestros pueblos y esa postura frente al recuerdo/olvido es la que le da el carácter culturalideológico que nosotros quisimos recuperar acá. Recoger el manuscrito de Rojas 
Padilla y hacerse cargo de su contenido es un gesto estético-político que Hombres de mar asume de principio a fin.

Un proyecto escritural el de Colchado que dialoga con el mito, la historia y la ficción. Contar la historia de estos hombres de mar requiere de esta interdiscursividad sin la cual no podría obtenerse una versión honesta y totalizadora de los hechos. Y esto por un problema que no es sólo textual, sino también real. El universo que se retrata está atravesado por estas múltiples realidades que rebasan el simple hecho histórico y al hombre como un ser unidimensional. La pesca, la huelga, la fiesta, el habitar, la muerte, son temas mayores que exigen ser estudiados desde todos los planos del saber. Si retomamos el conflicto de la muerte, por ejemplo, vemos que no es un hecho biológico o político, solamente. Es también un asunto mitológico ya que apela a un ritual, a una creencia ligada entrañablemente a los orígenes del pueblo de Chimbote. La sangre derramada, siguiendo esta lectura, aplacaría la sed del dios Ai-Apaec, logrando así la armonía necesaria, el equilibrio natural de los hombres con el universo. Puede ser, así, el resultado del compromiso que adquiriera Mellizo Marino cuando afirma que enmendará la falta contra su padre llevándole sangre fresca de los trabajadores de la bahía, y entonces todo el conflicto y la huelga son resultado de una trama cuya fuerza es mítica. O bien, por el lado histórico, todos estos temas tratados pueden ser consecuencia del capitalismo avanzado que ya estaba por esos años tomándose la actividad económica del puerto y de toda Latinoamérica, y que, inevitablemente, nos lleva también a retomar otro mito: el de Fausto $^{32}$. Siendo así, quedan reveladas las fuerzas demoniacas que impulsan la

32 El Fausto de Goethe, para Berman, no sólo la primera tragedia del desarrollo, sino también la mejor. Su valor radica en que simboliza la tragedia de la modernidad: el afán de trascender. Por medio de la razón instrumental, querer alcanzar la inmortalidad, desacatando con ello la tradición del cosmos antiguo en que la inmortalidad es exclusiva de los dioses. La ambición-insatisfacción de la ciencia y la inteligencia modernas llevarían al hombre (al doctor Fausto) a desobedecer el orden y, por medio de un arreglo, vender el alma al diablo para alcanzar la gloria inmortal. Lo interesante es que Berman lee el Fausto de Goethe a la luz del Manifiesto Comunista, diciendo que la burguesía es Fausto. En su ambición de poder, la burguesía quiere transformar el mundo hacia el límite del desarrollo y para eso le vende al diablo su fuerza de producción, las potencias infernales de la organización del trabajo (la mano de obra del proletariado). El dinero se sobrepone al hombre que en esta lógica desarrollista es considerado un obstáculo. Así, al rebasar todos los 
CATEDRAL Tomada: Revista de crítica literaria latinoamericana / Journal of Latin American Literary Criticism Espacios, discursos y modos de habitar Chimbote en Hombres de mar (de Óscar Colchado Lucio). Hacia una tradición de la poética de la frontera chimbotana.

explotación del trabajo pesquero en desmedro de la integridad del pescador. El puerto llevado en este sentido a sus límites de producción por el interés del capital burgués representado en la novela por Muki, el próspero empresario que no conforme con la anchoveta incursionará en la droga ${ }^{33}$. Son interpretaciones que en este ensayo quedarán abiertas. $\mathrm{O}$, por cierto, pueden ser todas a la vez, y así lograr dar sentido a este enfrentamiento y a todos los enfrenamientos del Perú moderno en que en la ciudad, en la selva, en la sierra se viene derramando la sangre del indio, del comunero, del negro, del pescador, del revolucionario, del poblador. Esto no es una justificación a la masacre, sino un modo de entender nuestro pasado donde, querámoslo o no, el sacrificio es inherente. No podemos contar nuestra historia sin la muerte, y en la medida que la asumamos como un hecho real y presente podremos condenar todo sacrificio, pero no sin antes conocer el complejo universo del hombre antiguo, para recién entonces comprender el efímero presente.

\section{Bibliografía}

Arguedas, José María. El zorro de arriba y el zorro de abajo. Buenos Aires: Losada, 1971.

Bachelard, Gastón. La poética del espacio. Buenos Aires: Fondo de Cultura Económica, 1991.

límites, incluso los morales, la burguesía pierde su decencia, su alma. He aquí pues la paradoja o dialéctica de la modernidad: que destruye mientras crea, y donde Marx revela tanto el poder destructivo de la razón burguesa como la fuerza potencial del proletariado (Berman Todo).

${ }^{33}$ Es evidente que la historia de la industria pesquera de Chimbote permite una interesante lectura desde esta figura del alma fáustica. Habría las condiciones para entender desde esta mirada que hace Berman Chimbote y el Perú moderno como una tragedia del desarrollo, como paradoja de nuestra modernidad regional. Un trabajo que se podría enriquecer con, entre otros tantos: Banchero. Los adolescentes y alucinantes años 60 de Chimbote (1973), de Guillermo Thorndike. 
Berman, Marshall. Todo lo sólido se desvanece en el aire. La experiencia de la modernidad. México: Siglo XXI, 1997.

Bolaño, Roberto. Amuleto. Barcelona: Anagrama, 2005.

Bourdieu, Pierre. Campo de poder, campo intelectual. Itinerario de un concepto. Buenos Aires: Montressor, 2002.

Certeau, Michel de. La invención de lo cotidiano. 1 Artes de hacer. México: Universidad Iberoamericana, 2000.

Colchado Lucio, Óscar. Hombres de mar. Lima: Alfaguara, 2011.

Cornejo Polar, Antonio. Escribir en el aire. Ensayo sobre la heterogeneidad socio-cultural en las literaturas andinas. Lima: Horizonte, 2003.

-----. 'Una heterogeneidad no dialéctica. Sujeto y discurso migrantes en el Perú moderno", Revista Iberoamericana, tomo LXII, n. 176-177, Lima (1996): 837-844.

$\mathrm{http} / / /$ revista-

iberoamericana.pitt.edu/ojs/index.php/Iberoamericana/article/ViewFi

le/6262/6438. 15 abril 2016.

-----. Sobre literatura y crítica latinoamericana. Caracas: Universidad Central de Venezuela, 1982.

Chandía Araya, Marco. "Hacia una poética de la frontera urbana, porteña y popular. Imaginarios chileno-peruanos, de los ojos imperiales a nuestra propia expresión". Tesis para optar al grado de Doctor en Literatura Chilena e Hispanoamérica. Universidad de Chile, 2012. http://repositorio.uchile.cl/bitstream/handle/2250/111092/Chandia\%20Marc o.pdf? sequence $=3 \&$ is Allowed $=\mathrm{y}$

Diez-Canseco, José. Obra narrativa completa. Edición crítica de T. G. Escajadillo. Lima: Amaru, 2005.

Lienhard, Martin. Cultura popular andina y forma novelesca. Zorros y danzantes en la última novela de Arguedas. México DF.: Ediciones Taller Abierto, 1998.

Martí, José. Obras escogidas en tres tomos. La Habana: Ciencias Sociales, 2002. 
CATEDRAL TOMADA: Revista de crítica literaria latinoamericana / Journal of Latin American Literary Criticism Espacios, discursos y modos de habitar Chimbote en Hombres de mar (de Óscar Colchado Lucio). Hacia una tradición de la poética de la frontera chimbotana.

Martín-Barbero, Jesús. "Memory and Form in the Latin American Soap Opera", To Be Continued...: Soap Operas around the World. London: Routledge, 1995.

Meschonnic, Henri. Poética do traduzir. São Paulo: Perspectiva, 2010.

Moraña, Mabel. Arguedas / Vargas Llosa. Dilemas y ensamblajes. Madrid: Iberoamérica, 2013.

Pary, Daniel. "Transnacionalización y la balada latinoamericana", en línea: https://sites.google.com/site/dparty/conferencepresentations/transnacionalizacion. (21/01/2016).

Rama, Ángel. Transculturación narrativa en América Latina. México: Siglo XXI, 1987.

Ramos, Julio. Desencuentros de la modernidad en América Latina. Literatura y política en el siglo XIX. México: Fondo de Cultura Económica, 2003.

Rojas, Manuel. Lanchas en la bahía. Santiago de Chile: Zig-Zag, 2002.

Sarmiento, Domingo Faustino. Facundo o Civilización y barbarie. Caracas: Biblioteca Ayacucho, 1977.

Sorel, Georges. Reflexiones sobre la violencia. Buenos Aires: Pléyade, 1973. 